\title{
Testing conceptual and physically based soil hydrology schemes against observations for the Amazon Basin
}

\author{
M. Guimberteau ${ }^{1,2}$, A. Ducharne ${ }^{1,2,3,4}$, P. Ciais ${ }^{1,2,5,6,7}$, J. P. Boisier ${ }^{1,2}$, S. Peng ${ }^{1,2,5,6,7,8}$, M. De Weirdt ${ }^{9}$, and \\ H. Verbeeck ${ }^{9}$ \\ ${ }^{1}$ Institut Pierre Simon Laplace (IPSL), Paris, France \\ ${ }^{2}$ Centre National de la Recherche Scientifique (CNRS), Paris, France \\ ${ }^{3}$ Unité Mixte de Recherche (UMR) METIS 7619, Paris, France \\ ${ }^{4}$ Université Pierre et Marie Curie (UPMC), Paris, France \\ ${ }^{5}$ Laboratoire des Sciences du Climat et de l'Environment (LSCE), 91191 Gif-sur-Yvette, France \\ ${ }^{6}$ Joint Unit of Commissariat à l'énergie atomique et aux énergies alternatives (CEA), Gif-sur-Yvette, France \\ ${ }^{7}$ Université de Versailles Saint-Quentin (UVSQ), Versailles, France \\ ${ }^{8}$ UJF Grenoble 1, Laboratoire de Glaciologie et Géophysique de 1'Environnement (LGGE, UMR5183), Grenoble, France \\ ${ }^{9}$ Laboratory of Plant Ecology, Department of Applied Ecology and Environmental Biology, \\ Faculty of Bioscience Engineering, Ghent University, Coupure Links 653, 9000 Ghent, Belgium
}

Correspondence to: M. Guimberteau (matthieu.guimberteau@upmc.fr)

Received: 21 November 2013 - Published in Geosci. Model Dev. Discuss.: 7 January 2014

Revised: 11 April 2014 - Accepted: 28 April 2014 - Published: 6 June 2014

\begin{abstract}
This study analyzes the performance of the two soil hydrology schemes of the land surface model ORCHIDEE in estimating Amazonian hydrology and phenology for five major sub-basins (Xingu, Tapajós, Madeira, Solimões and Negro), during the 29-year period 1980-2008. A simple 2-layer scheme with a bucket topped by an evaporative layer is compared to an 11-layer diffusion scheme. The soil schemes are coupled with a river routing module and a process model of plant physiology, phenology and carbon dynamics. The simulated water budget and vegetation functioning components are compared with several data sets at sub-basin scale. The use of the 11-layer soil diffusion scheme does not significantly change the Amazonian water budget simulation when compared to the 2layer soil scheme $(+3.1$ and $-3.0 \%$ in evapotranspiration and river discharge, respectively). However, the higher water-holding capacity of the soil and the physically based representation of runoff and drainage in the 11-layer soil diffusion scheme result in more dynamic soil water storage variation and improved simulation of the total terrestrial water storage when compared to GRACE satellite estimates. The greater soil water storage within the 11-layer scheme also results in increased dry-season evapotranspiration $\left(+0.5 \mathrm{~mm} \mathrm{~d}^{-1},+17 \%\right)$ and improves river discharge
\end{abstract}

simulation in the southeastern sub-basins such as the Xingu. Evapotranspiration over this sub-basin is sustained during the whole dry season with the 11-layer soil diffusion scheme, whereas the 2-layer scheme limits it after only 2 dry months. Lower plant drought stress simulated by the 11-layer soil diffusion scheme leads to better simulation of the seasonal cycle of photosynthesis (GPP) when compared to a GPP data-driven model based on eddy covariance and satellite greenness measurements. A dry-season length between 4 and 7 months over the entire Amazon Basin is found to be critical in distinguishing differences in hydrological feedbacks between the soil and the vegetation cover simulated by the two soil schemes. On average, the multilayer soil diffusion scheme provides little improvement in simulated hydrology over the wet tropical Amazonian sub-basins, but a more significant improvement is found over the drier sub-basins. The use of a multilayer soil diffusion scheme might become critical for assessments of future hydrological changes, especially in southern regions of the Amazon Basin where longer dry seasons and more severe droughts are expected in the next century. 


\section{Introduction}

The Amazon Basin plays an important role within the global water cycle. Among other factors, it is responsible for $15-$ $20 \%$ of the water discharged into the oceans (Molinier and Guyot, 1996). The complex hydrological functioning of the basin makes it an interesting and key subject for modeling studies (e.g., Coe et al., 2007; Decharme et al., 2008; Beighley et al., 2009; Trigg et al., 2009; Fan and MiguezMacho, 2010; Paiva et al., 2011; Guimberteau et al., 2012a; Paiva et al., 2012; Yamazaki et al., 2012). The large area of the basin (about 6 million $\mathrm{km}^{2}$ ) encompasses a large range of precipitation $(P)$ regimes with different seasonalities that partly modulate river discharge $(Q)$ in each sub-basin. The seasonality of $Q$ is further modulated by floodplains (Paiva et al., 2013). Its wide extent makes the Amazon Basin a key candidate to benefit from the Gravity Recovery And Climate Experiment (GRACE) satellite mission. GRACE data have indeed given reliable estimates of the dynamics of total terrestrial water storage (TWS) in the basin (Chen et al., 2009, 2010; Xavier et al., 2010; Becker et al., 2011; Frappart et al., 2013), which has helped in the evaluation of hydrological and land surface models (LSMs) (Syed et al., 2005, 2008; Crowley et al., 2008; Vergnes and Decharme, 2012) - critical if we are to achieve accurate modeling of the water, energy, and $\mathrm{CO}_{2}$ fluxes in Earth system models.

Soil moisture variations make an important contribution to TWS variations (Entekhabi et al., 1996; Yeh et al., 2006). Under specific conditions, soil moisture also controls the partitioning of surface net radiation into sensible versus latent heat flux, and consequently the evapotranspiration (ET) and the land-atmosphere feedbacks, which are one of the main sources of uncertainty in climate models (Koster et al., 2004b; Douville, 2010). Precipitation recycling is a particularly important land-atmosphere feedback in the Amazon Basin (Shuttleworth, 1988; Marengo, 2006). This process is affected by soil moisture in the southern parts of the basin, where a marked dry season limits soil moisture availability and hence ET. Seasonal and inter-annual droughts also affect the biosphere and carbon fluxes, although the size of this impact is still disputed (e.g., Keller et al., 2004; Lewis et al., 2011; Verbeeck et al., 2011; Gatti et al., 2014). The Amazon Basin is thus an interesting domain for evaluating soil moisture parameterizations.

As reviewed by Pitman (2003), soil hydrology parameterizations have evolved from conceptual bucket-type models, with one or two layers, in which soil moisture is described in terms of available moisture between the wiltingpoint and field capacity. Now, physically based models solve the Richards equation for water flow in unsaturated soil, relying on volumetric water content up to full saturation (Abramopoulos et al., 1988; Thompson and Pollard, 1995; Viterbo and Beljaars, 1995; Chen et al., 1997; Cox et al., 1999; Boone et al., 2000; De Rosnay et al., 2000; Dai et al., 2003; Decharme et al., 2011). This latter approach offers many advantages: (i) improved accounting of the spatial variability of soil properties (Gutmann and Small, 2005; Guillod et al., 2013); (ii) inclusion of processes that control soil moisture profiles, such as soil water infiltration and surface runoff generation (D'Orgeval et al., 2008), root water uptake for transpiration (Feddes et al., 2001), or hydraulic coupling to a water table (Liang et al., 2003; Gulden et al., 2007; Campoy et al., 2013); and (iii) comparability to satellite observations of soil moisture in the top zone (Reichle and Koster, 2005; Draper et al., 2011; De Rosnay et al., 2013). Very few studies, however, have quantified the differences between conceptual bucket-type models and multilayer models in simulating water fluxes in the terrestrial water budget. Confrontation with local-scale measurement has shown improved soil moisture control on ET by multilayer schemes in different domains (Mahfouf et al., 1996; De Rosnay et al., 2002; Decharme et al., 2011), including in the Amazon Basin (Baker et al., 2008). Hagemann and Stacke (2014) also analyzed the influence of the vertical discretization of soil moisture on soil moisture memory and land-atmosphere coupling in the ECHAM6/JSBACH climate model. Finally, in a study coupling the ORCHIDEE (ORganizing Carbon and Hydrology in Dynamic EcosystEms, Krinner et al., 2005) LSM to the IPSL (Institut Pierre Simon Laplace) climate model, Cheruy et al. (2013) showed that the multilayer version of ORCHIDEE increased modeled ET over Europe, giving better agreement with local observations, and reducing the midlatitude summer, warm bias of many climate models (Boberg and Christensen, 2012; Mueller and Seneviratne, 2014).

In this study, we use the ORCHIDEE LSM to address the question "Does the use of a multilayer soil diffusion scheme, rather than a simpler conceptual bucket-type scheme, improve the simulation of water storage dynamics and water fluxes in Amazonia?". To answer this question, we apply versions of ORCHIDEE fitted with these two soil hydrology schemes to the Amazon Basin and its main sub-basins, and evaluate the performance of each version against different hydrological (TWS and ET) and vegetation-related (leaf area index (LAI), gross primary production (GPP)) data sets.

We first give a brief description of the ORCHIDEE model in Sect. 2, including its carbon cycle module (Sect. 2.2). The two soil hydrology parameterizations and their coupling with the river-routing scheme are detailed in Sects. 2.3 and 2.4, respectively. The atmospheric forcing data and the different observations used to evaluate each version of ORCHIDEE, are described in Sect. 3. In Sect. 4, we evaluate the water budgets from the observations (Sect. 4.1.1) and the two soil hydrology schemes (Sect. 4.1.2) in five Amazonian subbasins (Solimões, Madeira, Tapajós, Xingu and Negro). In each sub-basin, simulated TWS is compared to GRACE observations (Sect. 4.2). ET and $Q$ differences between the two simulations are given in Sect. 4.3. We then focus on the Xingu sub-basin in the drier southeastern part of the Amazon Basin (Sect. 4.4) where soil moisture, and therefore its computation in the model, is likely to limit ET during the 
dry season (Da Rocha et al., 2009a, b) and may in turn affect dry season precipitation (Koster et al., 2004a). The Xingu case study is also justified because this sub-basin is expected to experience longer dry seasons, more severe droughts $(\mathrm{Li}$ et al., 2006, 2008) and lower minimum river discharge rates (Guimberteau et al., 2013) in the future. We test the sensitivity of the ET simulated by the two soil hydrology schemes to the dry season length over the Amazon Basin in Sect. 4.5.

\section{Model description}

\subsection{General land surface model}

ORCHIDEE is an LSM simulating energy, water and $\mathrm{CO}_{2}$ fluxes and ecosystem carbon cycling. It is the land component of the IPSL coupled climate model. In uncoupled simulations, feedbacks with the atmosphere are removed and the model is run offline, a mode frequently used to test model performance by comparison to observations, as in this study. ORCHIDEE includes two main modules:

1. SECHIBA (Schématisation des Echanges Hydriques à l'Interface entre la Biosphère et l'Atmosphère, Ducoudré et al., 1993; De Rosnay and Polcher, 1998) that simulates energy and water exchanges between the atmosphere and the land surface. SECHIBA includes the two soil hydrology configurations.

2. STOMATE (Saclay Toulouse Orsay Model for the Analysis of Terrestrial Ecosystems, Viovy, 1996), that simulates phenology and carbon dynamics. When coupled with SECHIBA, STOMATE links the fast hydrological and biophysical processes with the carbon dynamics. STOMATE also contains a dynamic vegetation model, but this module was not activated for this study.

\subsection{Vegetation modeling with STOMATE}

In each grid cell, up to 12 plant functional types (PFTs) can be represented simultaneously, in addition to bare soil. In the Amazon Basin, the dominant PFT is tropical broad-leaved evergreen forest $(83 \%)$ compared to $\mathrm{C} 4$ grassland $(7 \%)$, C3 grassland (5\%), tropical broad-leaved rain green forest $(3 \%)$ and others $(2 \%)$. Their fraction is adapted from the $1 \mathrm{~km}$ global land cover map (International Geosphere Biosphere Programme (IGBP); Belward et al., 1999) reduced by a dominant-type method to $5 \mathrm{~km}$ spatial resolution with the Olson classification (Olson et al., 1983). Maximal fraction of vegetation of each grid cell is thus defined. It is modulated by the leaf area index (LAI) growth, specific to each PFT represented in the model. LAI dynamics (from carbohydrate allocation) is simulated by STOMATE which models the allocation of assimilates, autotrophic respiration components, foliar development, mortality and litter and soil organic matter decomposition. A factor representing drought stress (McMurtrie et al., 1990) linearly computes the rate of ribulose bisphosphate $(\mathrm{RuBP})$ regeneration and the carboxylation rate. The drought stress and the leaf age of the vegetation directly influence the photosynthetic capacity (Farquhar et al., 1980; Collatz et al., 1992) and indirectly the stomatal conductance (Ball et al., 1987); they thus impact the transpiration.

\subsection{Soil hydrology modeling with SECHIBA}

SECHIBA is the physical module of ORCHIDEE and simulates water and energy fluxes from the soil, through the vegetation, into the atmosphere, at a $30 \mathrm{~min}$ time step. Two soil hydrology schemes (the 2-layer scheme (hereafter called "2LAY") and the 11-layer scheme (hereafter called "11LAY")) are available to simulate the soil water fluxes and storages that control runoff and ET fluxes. In both schemes, ET is the sum of evaporation of water intercepted by the canopy, transpiration (controlled by a stomatal conductance calculated by STOMATE as a function of water availability in the soil column and a fixed root density profile (De Rosnay and Polcher, 1998)), bare soil evaporation (which decreases with soil moisture in the top layer), snow sublimation and open water evaporation from floodplains. We give here a brief description of the two soil hydrology schemes, which are also summarized in Table 1.

\subsubsection{LAY}

The 2LAY scheme (Ducoudré et al., 1993; Guimberteau et al., 2012b) is frequently used with the STOMATE module, most recently for the Coupled Model Intercomparison Project Phase 5 (CMIP5) IPCC (Intergovernmental Panel on Climate Change) climate scenarios. It is a conceptual model, in which maximum water storage is regarded as the available water-holding capacity, between the wilting point and the field capacity, and globally set to $300 \mathrm{~kg} \mathrm{~m}^{-2}$ over a $2 \mathrm{~m}$ soil depth. The hydrological scheme relies on two layers linked by a downward water redistribution flux, involving three empirical parameters (Ducharne et al., 1998). The top layer is subject to root extraction and bare soil evaporation, which are both limited by a resistance depending on the layer's moisture (Ducoudré et al., 1993). The amount of water stored in this top layer is directly controlled by rain falling through the canopy; it can disappear when its water content is fully evaporated. The water content in the deep layer is only reduced by root extraction for transpiration, which depends on soil moisture and the root profile. Runoff is computed as in the bucket model of Manabe (1969) and occurs only when total soil moisture reaches the maximum water storage. In such a case, excess water is converted to runoff, which can be considered as Dunne runoff (Dunne and Black, 1970). In the 2LAY, a separate water budget is computed for each PFT tile within a mesh, and then averaged over the grid cell. 
Table 1. Main differences and similarities between the two soil hydrology schemes, the 2LAY and 11LAY.

\begin{tabular}{|c|c|c|}
\hline & 2LAY & 11LAY \\
\hline Number of soil moisture layers & 2 & 11 \\
\hline Soil depth & $2 \mathrm{~m}$ & $2 \mathrm{~m}$ \\
\hline Soil moisture range & Wilting point - Field capacity & Residual water content - Saturation \\
\hline $\begin{array}{l}\text { Max. water storage in this range } \\
\text { (average over the Amazon Basin) }\end{array}$ & $300 \mathrm{~kg} \mathrm{~m}^{-2}$ & $687 \mathrm{~kg} \mathrm{~m}^{-2}$ \\
\hline Infiltration processes & Unlimited until saturation & $\begin{array}{l}\text { Limited by hydraulic conductivity with enhancement } \\
\text { by roots, and re-infiltration in flat areas }\end{array}$ \\
\hline Surface runoff processes & Saturation excess (Dunne) & Infiltration excess (Horton) \\
\hline Soil moisture redistribution & $\begin{array}{l}\text { Downward flux between } \\
\text { the two layers with three parameters }\end{array}$ & $\begin{array}{l}\text { Following Richards equation with hydrodynamic } \\
\text { parameters based on the Mualem-Van Genuchten } \\
\text { model with vertical decay of saturated } \\
\text { hydraulic conductivity }\end{array}$ \\
\hline Drainage at the soil bottom & No & Gravitational drainage \\
\hline Dependance on soil texture & No & $\begin{array}{l}\text { Yes, for five parameters (residual and saturated water } \\
\text { contents, and three Mualem-Van Genuchten parameters) }\end{array}$ \\
\hline
\end{tabular}

\subsubsection{LAY}

The 11LAY scheme is described by De Rosnay et al. (2000, 2002) and Campoy et al. (2013). It has been used in the Amazon Basin for streamflow evaluation (Guimberteau et al., 2012a) and for studying future annual extreme flow variation under climate change (Guimberteau et al., 2013). The 11LAY simulates vertical water flows based on a physical description of water diffusion and retention in unsaturated soils, stemming from the Richards equation (Richards, 1931), which allows capillary rise. For numerical integration, the $2 \mathrm{~m}$ soil column is divided into 11 discrete layers, with thickness increasing geometrically with depth. The relationships between volumetric water content, hydraulic conductivity, and matric potential, are described in ORCHIDEE by the Mualem-Van Genuchten model (Mualem, 1976; Van Genuchten, 1980), using parameters defined by Carsel and Parrish (1988) as a function of soil texture. The saturated hydraulic conductivity is also modified (D'Orgeval et al., 2008) to take into account two properties that have opposite effects on conductivity (Beven and Germann, 1982; Beven, 1984): (1) increased soil compactness with depth and (2) enhanced infiltration capacity due to the presence of vegetation that increases soil porosity in the root zone.

Variation in soil texture among grid cells is taken into account by means of three different soil types (coarse, medium and fine textured). Their spatial distribution is diagnosed by interpolating the $1^{\circ} \times 1^{\circ}$ Food and Agriculture Organization texture map (FAO, 1978) by Zobler (1986), upscaled to the working resolution of ORCHIDEE by only keeping the dominant texture in each grid cell. In the Amazon Basin, this leads to saturated water contents between $820 \mathrm{~kg} \mathrm{~m}^{-2}$ (coarse and fine textures) and $860 \mathrm{~kg} \mathrm{~m}^{-2}$ (medium texture) in the 2-meter soil, with an average water storage capacity of $687 \mathrm{~kg} \mathrm{~m}^{-2}$ above the residual water content.
The vertically explicit modeling of soil water fluxes enables the 11LAY to use a more physically based runoff computation than can be used in the 2LAY (De Rosnay et al., 2002). The precipitation rate and the soil hydraulic conductivity govern the partitioning between soil infiltration and surface runoff production, which can be regarded as Hortonian runoff (Horton, 1933). Soil infiltration involves a timesplitting procedure whereby the wetting front moves with time through the soil layers, according to Green and Ampt (1911), and partial re-infiltration is allowed in grid cells where the local slope is $\leq 0.5 \%$ (D'Orgeval et al., 2008). The second contribution to total runoff is free gravitational drainage at the bottom of the soil. Finally, independent water budgets are computed over three groups of PFTs (grouping bare soil, trees, and grass/crops) within the mesh, before averaging over the grid cell.

\subsection{River-routing module}

The routing module (Polcher, 2003; Guimberteau et al., 2012a) calculates the daily continental runoff to the ocean. This scheme is based on a parameterization of water flows on a global scale (Miller et al., 1994; Hagemann and Dumenil, 1998). A global map of the major watersheds (Vörösmarty et al., 2000) delineates the basin boundaries and allocates one of eight possible directions to the water flow within each grid cell. The $0.5^{\circ} \times 0.5^{\circ}$ resolution of the basin map is higher than the resolution of the atmospheric forcing data commonly used and it is therefore possible to have more than one basin in an ORCHIDEE grid cell (sub-basins). Water is transferred between each sub-grid basin through three linear water reservoirs, with no direct interaction with the atmosphere (except over floodplain areas). In each sub-basin, total runoff is transformed into river discharge emanating from the so-called fast and slow reservoirs, designed to account 
for the delay and attenuation of overland flow and groundwater flow, respectively, at the grid-cell scale. These two reservoirs are fed by surface runoff and drainage when using the 11LAY, and by an arbitrary partitioning of total runoff when using the 2LAY, with $5 \%$ feeding the fast reservoir and $95 \%$ feeding the slow reservoir (Ngo-Duc et al., 2007). Outflow from these two reservoirs becomes streamflow at the outlet of the sub-basin, and feeds the stream reservoir of the next downstream sub-basin, which also receives inflow from all upstream stream reservoirs.

Travel time within the reservoirs depends on a characteristic timescale, which is the product of a topographical water retention index $k$ (in $\mathrm{m}$ ) and a time constant $g$ (in $\mathrm{d} \mathrm{m}^{-1}$ ). The latter does not vary horizontally but distinguishes the three reservoirs, while k characterizes the impact of topography on travel time in each sub-basin, and is assumed to be the same in the three reservoirs of a given grid cell, even though it derives from stream-routing principles introduced by Ducharne et al. (2003). This travel time is thus assumed to be proportional to stream length in the sub-basin, and inversely proportional to the square root of stream slope. This can be seen as a simplification of the Manning formula (Manning, 1895), where the time constant $g$ compensates for the missing terms. The lengths and slopes are first computed at the $0.5^{\circ} \times 0.5^{\circ}$ resolution from the topographical map of Vörösmarty et al. (2000), then upscaled to the ORCHIDEE grid-cell resolution, of $1^{\circ} \times 1^{\circ}$ in the present study (Sect. 3.1). The values of the time constants, $g$, were initially calibrated over the Senegal Basin, using the 2LAY parameterization with the $5 / 95 \%$ partitioning of total runoff into the fast/slow reservoirs, then generalized for all the basins of the world (NgoDuc et al., 2007). The stream reservoir has the lowest constant $\left(0.24 \mathrm{~d} \mathrm{~m}^{-1}\right)$, which leads to a stream velocity of around $0.5 \mathrm{~m} \mathrm{~s}^{-1}$ assuming a slope of $1 \%$, both values being typical of large rivers. The corresponding velocities are lower in the other two reservoirs, with $g$ values of 3.0 and $25 \mathrm{~d} \mathrm{~m}^{-1}$ in the fast and slow reservoirs, respectively. In former studies using the 11LAY, the time constants of these two reservoirs have been set equal to the one of the fast reservoir $\left(g=3.0 \mathrm{~d} \mathrm{~m}^{-1}\right)$ to balance a higher water residence time in the soil with the 11LAY (D'Orgeval, 2006; D'Orgeval et al., 2008; Gouttevin et al., 2012; Guimberteau et al., 2012a, 2013). In the present study, however, to restrict the differences between model runs to the soil hydrology schemes alone, we used the same set of time constants with both the 2LAY and 11LAY: viz., $g=0.24,3.0,25 \mathrm{~d} \mathrm{~m}^{-1}$, as defined by Ngo-Duc et al. (2007).

The routing scheme also includes a floodplain/swamp parameterization (D'Orgeval et al., 2008), recently improved by Guimberteau et al. (2012a) for the Amazon Basin, by introducing a new floodplain/swamp map. Over these flooded areas, the water from the upstream reservoirs is delayed in a floodplain reservoir before going into the stream reservoir. The time constant of the floodplain reservoir is the same, for both soil hydrology schemes, and equal to that found by
Guimberteau et al. (2012a) who calibrated it for the Amazon $\operatorname{Basin}\left(2.5 \mathrm{~d} \mathrm{~m}^{-1}\right)$.

\subsection{Comparison of the two soil hydrology schemes}

To facilitate their comparison, the 2LAY and the 11LAY are used here with the same $2 \mathrm{~m}$ soil depth and the same PFTdependent root density profiles. They are both coupled to the same soil thermal scheme (using a 7-layer discretization over $5.5 \mathrm{~m}$ ), to the same routing module, and to the STOMATE vegetation module.

The differences between the hydrological simulations performed with these two schemes (described in Sect. 3.1, and analyzed in Sect. 4), are together due to the different description of soil water flow and storage, and to the related parameters (Table 1), because these two components are intimately linked. This is not particular to the present study, but is true of any comparison between a soil hydrology scheme that relies on available water content (between wilting point and field capacity), with conceptual parameterization of soil water flow, and a scheme that is physically based, and relies on volumetric water content (between residual moisture and saturation) and the Richards equation.

In the present case, additional differences between the simulations arise from the way total runoff is transferred to the fast and slow reservoirs of the routing scheme, modeled to receive surface runoff and drainage, respectively. The 11LAY makes a clear physical distinction between these two fluxes, in contrast to the $2 \mathrm{LAY}$, which creates total runoff only when the soil reservoir is full, with no clear surface or bottom localization, as in the bucket scheme of Manabe (1969). In this case, the routing scheme has always been used with a 5$95 \%$ redistribution of total runoff to the fast and slow routing reservoirs, respectively. In this paper, we follow this choice, stemming from Ngo-Duc et al. (2007), which has an impact on the relative contribution of these fast and slow reservoirs to TWS (as analyzed in Sect. 4.2).

\section{Methods and data sets}

\subsection{Simulation design and forcing data sets}

ORCHIDEE is forced by the Princeton Global Forcing (Sheffield et al., 2006) at a $1^{\circ} \times 1^{\circ}$ spatial resolution. It is based on the National Center for Environmental PredictionNational Center for Atmospheric Research (NCEP-NCAR) reanalysis data sets (Kistler et al., 2001). The temporal resolution is 3 hours and the time series cover the period 19482008. All the required forcing variables (see Table $\mathrm{S} 1$ in the Supplement) come directly from NCEP-NCAR, except the precipitation. The latter has been corrected using the monthly CRU (Climatic Research Unit) data set (New et al., 2000) and statistically downscaled from $2^{\circ} \times 2^{\circ}$ to $1^{\circ} \times 1^{\circ}$ resolution using relationships developed with the Global Precipitation Climatology Project (GPCP, Huffman et al., 2001) 


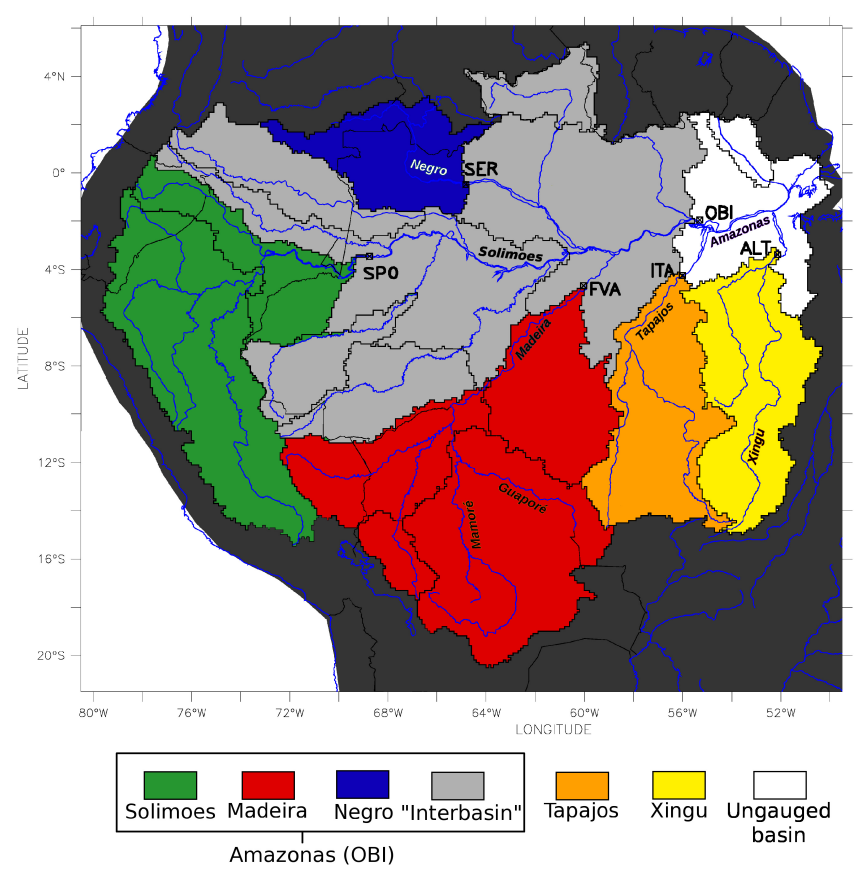

Figure 1. Map of the Amazon sub-basins and their gauging stations. Color is used to indicate the sub-basins studied here. Modified from Guimberteau et al. (2012a).

daily product. A similar method has been used to disaggregate from daily to 3-hourly using the Tropical Rainfall Measuring Mission (TRMM; Huffman et al., 2007) satellite data product. For this study, the precipitation data were further corrected by a new product (Version 5) of GPCC (Global Precipitation Climatology Centre; Schneider et al., 2014) (19012009), which seems to be the better global product for hydrological applications (Decharme and Douville, 2006).

Two simulations, with the 2LAY and then with the 11LAY, were performed using SECHIBA coupled with STOMATE, the routing scheme and the floodplain parameterization. Each simulation was for 34 years (1975-2008), the first 5 years of the period being discarded in order to ensure a state of hydrological equilibrium at the beginning of the analyzed time series. Thus, the 29-year period from 1980 to 2008 is analyzed for the Amazon Basin and its five large sub-basins: the Madeira, Tapajós and Xingu in the south, the Solimões in the west and the Negro in the north (Fig. 1).

\subsection{Evaluation data sets}

Several data sets (Table 2) were used to evaluate the hydrology, the carbon fluxes and the phenology simulated by ORCHIDEE. This comparison aims to determine whether the 11LAY gives a better representation of Amazonian hydrology and vegetation feedback than the 2LAY.

\subsubsection{Total terrestrial water storage (TWS)}

TWS is the integrated water amount stored on and below the land surface. In this study, we use the monthly terrestrial water storage variations from the GRACE data set, which are derived from a satellite mission mapping the earth's gravitational field. We use the latest solution RL05 "DSTvSCS1401" produced by the University of Texas at Austin/Center for Space Research (CSR). To compare the TWS simulated by ORCHIDEE to GRACE data, we calculate from ORCHIDEE outputs the sum of soil moisture, snowpack (negligible in Amazonia), water on the canopy and the free water stored in the four water routing reservoirs. GRACE data cover the 12-year period April 2002October 2013 and are expressed as the difference in water depth equivalent from the 5-year average for 2003-2007. In each grid cell, the corresponding 5-year average is removed from the 2003-2008 studied time series of TWS output from ORCHIDEE. The GRACE data were filtered and corrections applied for bias and leakage (Swenson and Wahr, 2002, 2006). GRACE measurements are particularly accurate over the Amazon Basin where TWS error is estimated to be $15 \mathrm{~mm}$ (i.e., about $4.2 \%$ of the TWS annual amplitude) (Wahr et al., 2004). Comparison of simulated TWS with GRACE data is only recommended over river basins having areas of $400000 \mathrm{~km}^{2}$ or larger (Swenson et al., 2003). The Amazon Basin, which extends over about 6 million $\mathrm{km}^{2}$, is therefore suitable. The Amazon sub-basins on which we focus also have areas greater than $400000 \mathrm{~km}^{2}$, except for the Negro sub-basin, which is close to $300000 \mathrm{~km}^{2}$ in area (Table 3 ). Thus, the results of TWS over this sub-basin should be taken with caution.

\subsubsection{Basin-scale water budget}

\section{Precipitation $(P)$}

A precipitation data set for the Amazon Basin has recently been collected and harmonized by the ORE (Environmental Research Observatory) HYBAM (Geodynamical, hydrological and biogeochemical control of erosion/alteration and material transport in the Amazon Basin - http://www. ore-hybam.org). This data set is independent from the one produced by Sheffield et al. (2006). Daily in situ rain gauge observations from the meteorological services of Amazonian countries have been interpolated at $1^{\circ} \times 1^{\circ}$ resolution over the basin. The correction of CRU-NCEP precipitation by the ORE HYBAM data set contributed to significant improvements in river discharge simulation with ORCHIDEE (Guimberteau et al., 2012a).

\section{Evapotranspiration (ET) and gross primary productivity (GPP)}

The increased number of in situ ET measurements and more advanced satellite remote sensing algorithms now 
Table 2. List of evaluation data sets.

\begin{tabular}{|c|c|c|c|c|c|c|}
\hline Variable & Data set & \multicolumn{2}{|c|}{ Resolution } & \multicolumn{2}{|l|}{ Coverage } & References \\
\hline TWS change & GRACE & $1.0^{\circ}$ & Monthly & Global & 2002-2013 & Bettadpur (2012) \\
\hline \multirow[t]{2}{*}{$Q$} & ORE HYBAM & Station & Monthly & Amazon Basin (scattered) & 1980-2011 & Cochonneau et al. (2006) \\
\hline & MTE-ET & $0.5^{\circ}$ & Monthly & Global & 1982-2008 & Jung et al. (2010) \\
\hline ET & PKU-ET & $0.5^{\circ}$ & Monthly & Global & 1982-2009 & Zeng et al. (2014) \\
\hline GPP & MTE-GPP & $0.5^{\circ}$ & Monthly & Global & 1982-2008 & Jung et al. (2011) \\
\hline LAI & GIMMS & $(1 / 12)^{\circ}$ & Half-monthly & Global & 1982-2011 & Zhu et al. (2013) \\
\hline
\end{tabular}

Table 3. List of ORE HYBAM gauging stations over the Amazon Basin. $Q_{\text {mean }}$ is the mean annual discharge from ORE HYBAM data, averaged over the period 1980-2008.

\begin{tabular}{lrrrrrrr}
\hline Station & & River & Lat & Lon & $\begin{array}{r}Q_{\text {mean }} \\
\left(\mathrm{m}^{3} \mathrm{~s}^{-1}\right)\end{array}$ & $\begin{array}{r}Q_{\text {mean }} \text { contribution } \\
\text { at OBI }(\%)\end{array}$ & $\begin{array}{r}\text { Basin area } \\
\left(\mathrm{km}^{2}\right)\end{array}$ \\
\hline Óbidos & OBI & Amazonas & -1.95 & -55.30 & 179263 & 100 & 4680000 \\
Altamira & ALT & Xingu & -3.38 & -52.14 & 7900 & - & 469100 \\
Itaituba & ITA & Tapajós & -4.24 & -56.00 & 11767 & - & 461100 \\
Fazenda Vista Alegre & FVA & Madeira & -4.68 & -60.03 & 27705 & 15 & 1293600 \\
São Paulo de Olivença & SPO & Solimões & -3.45 & -68.75 & 46717 & 26 & 990781 \\
Serrinha & SER & Negro & -0.48 & -64.83 & 16363 & 9 & 291100 \\
\hline
\end{tabular}

enable ET to be mapped at a global scale. For this study, we use ET estimates from Jung et al. (2010). This product, hereafter called "MTE-ET" (Model Tree EnsembleEvapoTranspiration), was derived from an empirical upscaling of FLUXNET eddy-covariance measurements using a machine-learning algorithm called MTE. The FLUXNET global network collects continuous in situ measurements of land-surface fluxes. Data from 253 globally distributed flux towers (4 in the Amazon Basin) were processed, corrected and combined with monthly gridded global meteorological data and the remotely sensed fraction of absorbed photosynthetically active radiation (Advanced Very High Resolution Radiometer (AVHRR), Sea-viewing Wide Field-of-view Sensor (SeaWiFS) and MEdium Resolution Imaging Spectrometer (MERIS)). The MTE-ET product has already been used for the evaluation of coupled and uncoupled LSM simulations (Mueller et al., 2011) and contributed to the creation of global long-term records of the terrestrial water budget (Pan et al., 2012).

Vegetation gross primary production (GPP) quantifies the gross $\mathrm{CO}_{2}$ flux taken up during photosynthesis. Jung et al. (2011) provided a global data-driven GPP product (hereafter called MTE-GPP) using a similar algorithm to that used to give ET.

Here, Jung et al.'s (2010) product is chosen to evaluate ET simulated by ORCHIDEE because it also provides a consistent GPP product. Uncertainties around this ET estimate are assessed by comparison with three other products: GLEAMET (Miralles et al., 2011), NTSG-ET (Zhang et al., 2010) and PKU-ET (Zeng et al., 2014).

\section{River discharge $(Q)$}

River discharge data have been collected and harmonized by the ORE HYBAM project (Cochonneau et al., 2006). The same database used by Guimberteau et al. (2012a) is updated up to 2011. Six river-gauging stations (Table 3), representative of the main sub-basins of the Amazon Basin (Fig. 1), are used to evaluate river discharge simulated by ORCHIDEE. Óbidos $(\mathrm{OBI})$ is the last gauging station before the mouth of the Amazon and is thus the most representative station to assess the average simulated river flow over the whole basin. The station Fazenda Vista Alegre (FVA) measures the discharge of the Madeira sub-basin, in the southern part of the Amazon Basin. The Madeira sub-basin has the largest contributing area and provides nearly $15 \%$ of the total river flow measured at Óbidos. The largest contribution, however, comes from the western region, gauged at São Paulo de Olivença (SPO) on the Rio Solimões, where the average river-flow is about $26 \%$ of the total flow measured at Óbidos. The Negro sub-basin at Serrinha (SER) has the lowest area, but makes a large contribution to the total discharge due to the high precipitation. The two southeastern sub-basins of the Tapajós and the Xingu rivers, gauged at Itaituba (ITA) and 
Altamira (ALT) respectively, flow into the Amazon downstream of the Óbidos station.

For each gauging station, we estimate an empirical basin lag time as the delay between the peaks of precipitation and river discharge due to the time required for runoff to travel to the basin outlet. This lag depends on the basin characteristics (size, soil, geology, slope, land use, etc.). The Amazon Basin hydrograph exhibits a basin lag time of about 4 months mainly due to the large size of the basin and the long residence time of water in the floodplains. The basin lag is lower (about 1 month) in the smaller sub-basins such as the Tapajós and the Negro. For the purpose of water budget estimation, we use an equivalent runoff, $Q^{*}$, as the discharge $Q$ time series, back-shifted using the empirical lag.

\section{Residual water balance $(\dot{\Delta} S)$}

The water balance equation gives the change in total water storage $\dot{\Delta} S=\Delta S \Delta t$, the residual of $P$-ET- $Q^{*}$, including soil water, groundwater, rivers and floodplains. It represents the amount of water that enters the system during the wet season $(\dot{\Delta} S>0)$ or is released $(\dot{\Delta} S<0)$ during the dry season. The mean annual change in storage is assumed to be negligible $(\overline{\dot{\Delta} S} \simeq 0)$. However, inconsistencies between the different observation data sets could lead to a non-zero annual water storage $(\overline{\dot{\Delta} S} \neq 0)$. The water balance closure condition is not fulfilled over the Solimões (bias of $-25 \%$ ), the Xingu $(-10 \%)$ and the Negro $(-6 \%)$ sub-basins, probably due to the underestimated precipitation in the ORE HYBAM data set over the western and northwestern sub-basins (Azarderakhsh et al., 2011; Guimberteau et al., 2012a) or to the low density of flux towers measuring ET over the Amazon Basin in the MTE-ET product. For the Amazon, the Tapajós and the Madeira basins, the bias is between -5 and $-2 \%$.

\subsubsection{Leaf area index (LAI)}

A leaf area index (LAI) data set is critical for monitoring global vegetation dynamics. For this study we use a product from Zhu et al. (2013), based on a neural network algorithm which combines the third generation Global Inventory Modeling and Mapping Studies (GIMMS) Normalized Difference Vegetation Index (NDVI3g) and best-quality Terra Moderate Resolution Imaging Spectroradiometer (MODIS) LAI for the period 2000-2009. This period overlaps the 2003-2008 studied time series of TWS output from ORCHIDEE. The comparison of the LAI with 45 sets of field measurements from 29 sites representative of all major biomes indicated a reasonable agreement $(p<0.001$; RSE $=0.68 \mathrm{LAI}$, Zhu et al., 2013).

\subsection{TWS amplitude and phase assessment}

To give an accurate estimate of the difference in TWS change between ORCHIDEE and GRACE, we use two indicators measuring the amplitude ( $\alpha$ in $\mathrm{mm}$ ) and the phase ( $\phi$ in days) of the TWS seasonal cycles. The phase is computed by a fit to the cosine function as follows:

$$
\begin{aligned}
Y & =p_{0}+p_{1} \cos \left(\frac{2 \pi D}{365}-\frac{\phi_{1} 2 \pi}{365}\right)+p_{2} \cos \left(\frac{4 \pi D}{365}-\frac{\phi_{2} 2 \pi}{365}\right) \\
& +p_{3} \cos \left(\frac{8 \pi D}{365}-\frac{\phi_{3} 2 \pi}{365}\right),
\end{aligned}
$$

where $Y$ is TWS, $D$ is the day of the year, $\phi_{1}, \phi_{2}$ and $\phi_{3}$ are the phases of the seasonality, and $p_{0}, p_{1}, p_{2}$ and $p_{3}$ are regression parameters. For the phase difference, only the phase of the first harmonic ( $\phi_{1}$ in Eq. 1$)$ is considered here. The amplitude is defined as $2 p_{1}$.

\section{Results and discussion}

\subsection{Water budgets for the Amazon sub-basins}

\subsubsection{Overview of observed water budgets}

Water budgets are first calculated from the different sets of observations: $P$ (ORE HYBAM), ET (MTE-ET) and $Q$ (ORE HYBAM) (Table 4). From these "observed" basinlevel water budgets, the estimated precipitation amount over the Amazon Basin is $6.2 \mathrm{~mm} \mathrm{~d}^{-1}$. Half of this water runs off to the mouth $\left(3.3 \mathrm{~mm} \mathrm{~d}^{-1}\right)$ and the other half evaporates $\left(3.2 \mathrm{~mm} \mathrm{~d}^{-1}\right)$ in agreement with the estimates by Shuttleworth (1988) (based on on-site measured $P$ and ET estimated from a model calibrated against micro-meteorological measurements) and Callede et al. (2008) (based on $P$ and $Q$ observations). Monthly precipitation averaged over the Amazon Basin is between $3.5 \mathrm{~mm} \mathrm{~d}^{-1}$ in August and $8.2 \mathrm{~mm} \mathrm{~d}^{-1}$ in February (Fig. 2a). This is reflected in the western Solimões sub-basin (Fig. 2e), which receives an annual average $P=$ $5.7 \mathrm{~mm} \mathrm{~d}^{-1}$. The seasonal amplitude of precipitation is larger in the Madeira sub-basin (Fig. 2d) which includes southern tropical regions subject to the seasonal displacement of the Intertropical Convergence Zone (ITCZ). The JJA dry season is also particularly marked in the Xingu and Tapajós subbasins in the southeast (Fig. 2b and c, respectively), with dry-season precipitation close to zero. By contrast, the DJF wet-season precipitation for those sub-basins averages about $10.0 \mathrm{~mm} \mathrm{~d}^{-1}$. The northern tropical sub-basin of the Rio Negro (Fig. 2f) receives high precipitation throughout the year $\left(8.7 \mathrm{~mm} \mathrm{~d}^{-1}\right)$ with a maximum in May $\left(12.0 \mathrm{~mm} \mathrm{~d}^{-1}\right)$.

In contrast to the precipitation, the seasonal cycle of ET is flat during the year over the Amazon Basin and its subbasins. The mean annual value varies between $3.0 \mathrm{~mm} \mathrm{~d}^{-1}$ for the Solimões and $3.4 \mathrm{~mm} \mathrm{~d}^{-1}$ for the Xingu.

Thus, total water storage (and consequently $Q$ ) seasonal variations are strongly modulated by the precipitation seasonality. In the southern sub-basins (Xingu, Tapajós and Madeira), water storage increases from October to April. The dry season occurs from May to September and is highlighted in JJA by an ET much higher (up to about $+3.0 \mathrm{~mm} \mathrm{~d}^{-1}$ 
(a) Amazon (OBI)

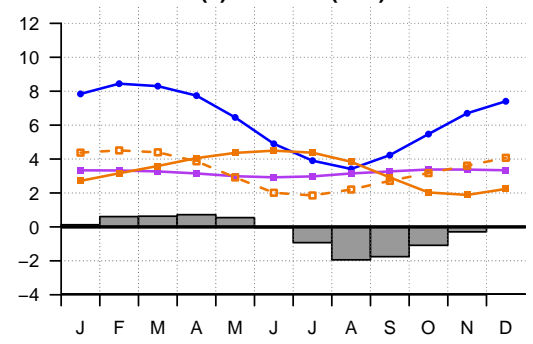

(c) Tapajos (ITA)

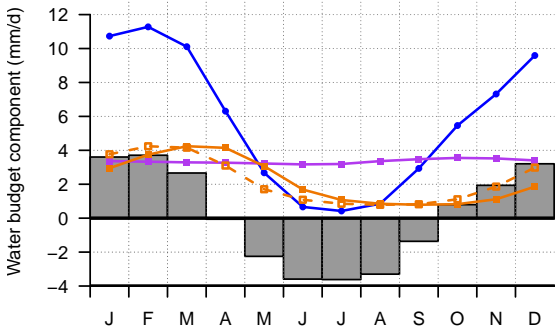

(e) Solimoes (SPO)

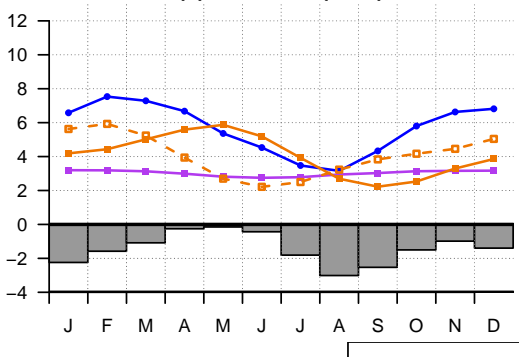

(b) Xingu (ALT)

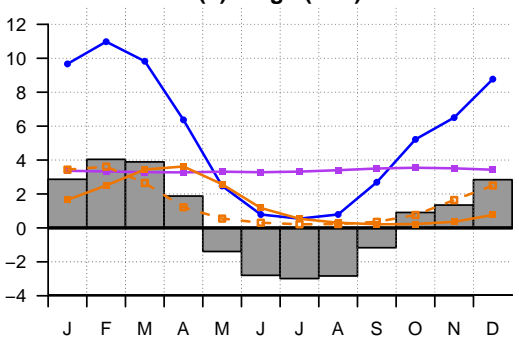

(d) Madeira (FVA)

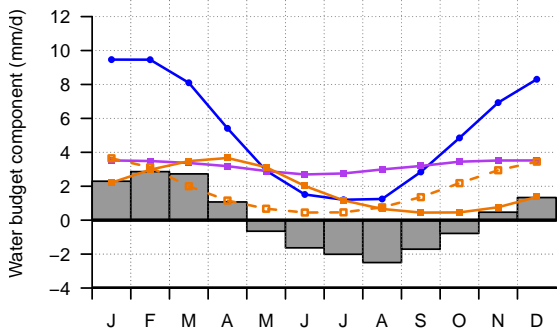

(f) Negro (SER)

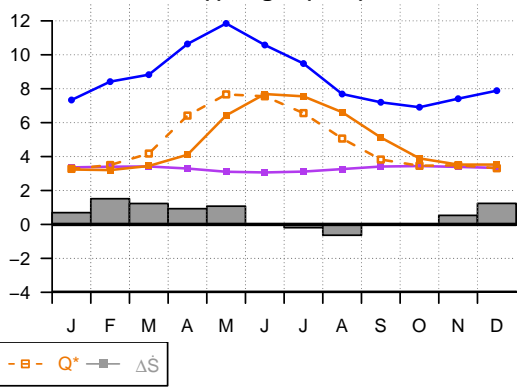

Figure 2. Monthly mean seasonalities of the water budget components $\left(\mathrm{mm} \mathrm{d}^{-1}\right)$ from observations, for the Amazon Basin and its subbasins, averaged over the period 1980-2008. $Q^{*}$ is the equivalent runoff as the discharge $Q$ time series, back-shifted using the empirical lag. The change in total water storage $\dot{\Delta} S$ is estimated as the residual of $P$-ET- $Q^{*}$.

for the southeastern sub-basins) than precipitation, which is close to zero, leading to severe low flow. The results in water storage change derived from water fluxes of several data sets should be taken with caution for the Solimões and Negro sub-basins, due to the large errors in water balance closure estimated in Sect. 3.2.2.

\subsubsection{Simulated water budgets}

The water budgets simulated by the two soil hydrology schemes and their bias with the observations are given in Table 4. Annual precipitation from Sheffield's forcing data is close to the ORE HYBAM over the Amazon Basin $(-1.2 \%)$ and its sub-basins (between $-3.2 \%$ for the Madeira and $+2.4 \%$ for the Solimões). The good agreement between simulated annual river discharge at Óbidos and ORE HYBAM data $(\leq 6 \%)$ results from a compensation between an overestimation in the south (between +15 and $+25 \%$ for the Madeira) and an underestimation in the western sub-basin (around $-15 \%$ for the Solimões), as already reported by Guimberteau et al. (2012a). In addition to the uncertainty in the forcing precipitation, the bias in river discharge may be explained by the low ET simulated by ORCHIDEE (between $-13 \%$ for the Xingu and the Madeira to $-20 \%$ for the Solimões with the 11LAY) when compared to MTE-ET. However, the ET underestimation by ORCHIDEE for the Amazon Basin $(-15 \%)$ is within the estimated error of annual MTE-ET $( \pm 13 \%)$ (see error bars in Fig. 1d for the bioclimatic zone "equatorial, fully humid" in Jung et al., 2010). The underestimation in both ET and $Q$ over the Solimões sub-basin suggests a disagreement between the evaluation data sets.

Over each sub-basin, the 11LAY systematically simulates a better water budget than the 2LAY. However, the differences in the results between the two soil hydrology schemes are small over the Amazon Basin.

\subsection{Total water storage change and contribution from the different reservoirs}

Seasonal (Sect. 4.2.1) and interannual (Sect. 4.2.2) variations in TWS from the two soil hydrology versions of ORCHIDEE 
Table 4. Mean annual values ( $\mathrm{mm} \mathrm{d}^{-1}$ ), and bias against the observations (in $\mathrm{mm} \mathrm{d}^{-1}$ and $\%$ in brackets), of the water budget components simulated by the 2LAY and 11LAY, for each sub-basin, averaged over the period 1980-2008. The bold values indicate the smallest bias between the 2LAY and 11LAY for a given sub-basin.

\begin{tabular}{|c|c|c|c|c|c|c|c|c|c|c|c|c|}
\hline & \multicolumn{4}{|c|}{ Amazon (OBI) } & \multicolumn{4}{|c|}{ Xingu (ALT) } & \multicolumn{4}{|c|}{ Tapajós (ITA) } \\
\hline & $P$ & ET & $Q$ & $\dot{\Delta s}$ & $P$ & ET & $Q$ & $\dot{\Delta s}$ & $P$ & ET & $Q$ & $\dot{\Delta s}$ \\
\hline 2LAY & & 2.6 & 3.5 & 0 & & 2.8 & 2.6 & 0 & 57 & 2.7 & 3.0 & 0 \\
\hline 11LAY & 6.1 & 2.7 & 3.4 & 0 & 5.4 & 2.9 & 2.5 & 0 & 5.7 & 2.9 & 2.8 & 0 \\
\hline \multirow[t]{2}{*}{ Obs } & 6.2 & 3.2 & 3.3 & -0.3 & 5.4 & 3.4 & 1.5 & +0.5 & 5.7 & 3.3 & 2.2 & +0.2 \\
\hline & \multicolumn{4}{|c|}{ Bias } & \multicolumn{4}{|c|}{ Bias } & \multicolumn{4}{|c|}{ Bias } \\
\hline $\begin{array}{c}\text { 2LAY } \\
11 \mathrm{LAY}\end{array}$ & $-0.1(-1.2)$ & $\begin{array}{c}-0.5(-17) \\
\mathbf{- 0 . 5}(-\mathbf{1 5})\end{array}$ & $\begin{array}{l}+0.2(+6) \\
+\mathbf{0 . 1}(+4)\end{array}$ & & $0(+0.1)$ & $\begin{array}{c}-0.6(-17) \\
-\mathbf{0 . 5}(-\mathbf{1 3})\end{array}$ & $\begin{array}{l}+1.1(+94) \\
+\mathbf{1 . 0}(+\mathbf{8 3})\end{array}$ & & $0(0)$ & $\begin{array}{c}-0.6(-18) \\
-\mathbf{0 . 4}(-\mathbf{1 5})\end{array}$ & $\begin{array}{l}+0.8(+31) \\
+\mathbf{0 . 6}(+27)\end{array}$ & \\
\hline
\end{tabular}

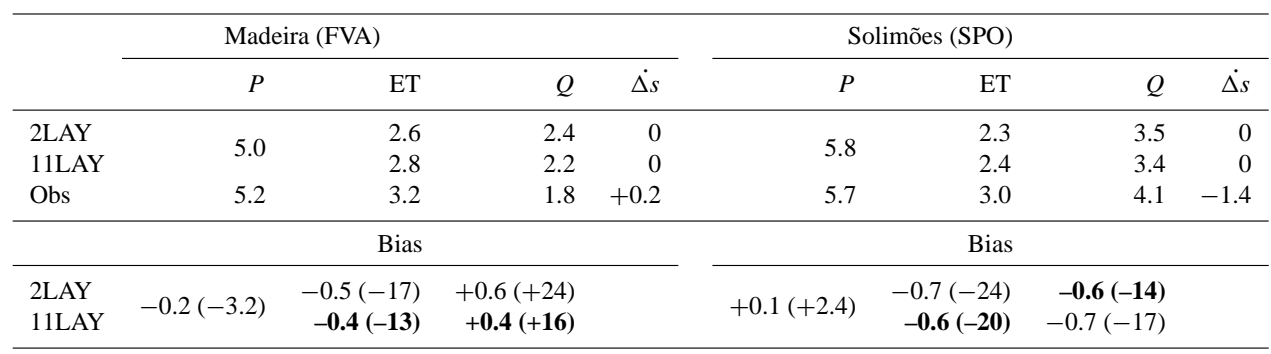

\begin{tabular}{|c|c|c|c|c|}
\hline \multicolumn{5}{|c|}{ Negro (SER) } \\
\hline & $P$ & ET & $Q$ & $\dot{\Delta s}$ \\
\hline 2LAY & & 2.8 & 5.6 & 0 \\
\hline 11LAY & 8.4 & 2.8 & 5.6 & 0 \\
\hline Obs & 8.7 & 3.3 & 4.9 & +0.5 \\
\hline \multicolumn{5}{|c|}{ Bias } \\
\hline $\begin{array}{l}2 \mathrm{LAY} \\
11 \mathrm{LAY}\end{array}$ & $-0.3(-3.0)$ & $\begin{array}{r}-0.5(-15) \\
-0.5(-14)\end{array}$ & $\begin{array}{r}+0.7(+15) \\
+\mathbf{0 . 7}(+\mathbf{1 5})\end{array}$ & \\
\hline
\end{tabular}

are compared to the GRACE data over the Amazon Basin and its sub-basins, during the 2003-2008 period.

\subsubsection{Seasonal variation}

The two different soil hydrology schemes simulate a similar TWS seasonal cycle over the entire Amazon Basin (Fig. 3a), with a half-monthly delay and an overestimated amplitude of about 7 and $14 \%$ compared to GRACE data, for the 2LAY and 11LAY, respectively (see Table S2 in the Supplement). This positive amplitude bias is predominant along the Amazonian rivers (main stem of the Amazon and the Madeira, Tapajós and Xingu, see Fig. S1a and b in the Supplement) suggesting the routing reservoir storages play a prevalent role in the overestimation of the TWS seasonal amplitude. The 11LAY is better at representing the TWS decrease, leading to better capture of the timing of the TWS minima. More strikingly, the five water storage reservoirs of the model contribute to TWS in different ways, according to which soil hydrology scheme is used. In both simulations, changes in the slow reservoir water content (green in Fig. 3a) make the largest contribution to total TWS change. The annual amplitude in water storage in the slow reservoir, which collects drainage, is lower with the 11LAY (46\% of the total annual amplitude of TWS) than with the 2LAY (66\%). Subsurface water contribution (sum of the fast, slow and soil reservoirs) to TWS variation simulated by the 11LAY (71\%) is in agreement with the estimations of Pokhrel et al. (2013) (71\%) over the Amazon Basin. The physical distinction between surface runoff and drainage in the 11LAY leads to a lower drainage contribution to the total runoff from the Amazon Basin $(\sim 69 \%)$, which is more realistic when compared to the estimates of Mortatti et al. (1997) (68.1\%), than with the 2LAY (95\%) (see Table S3 in the Supplement). By contrast, more water is stored in the soil (in blue) with the 11LAY (19\% of the total annual amplitude of TWS compared to $6 \%$ with the $2 \mathrm{LAY}$ ) thanks to the higher soil waterholding capacity of the 11LAY. The combination of these two effects leads to a better agreement with GRACE in the 11LAY simulation (see Table S4 in the Supplement for correlations).

According to GRACE data, the southern sub-basins (Xingu, Tapajós and Madeira) exhibit a pronounced TWS seasonal cycle (Fig. $3 b$ to d), which is due to the high annual 
(a) Amazon
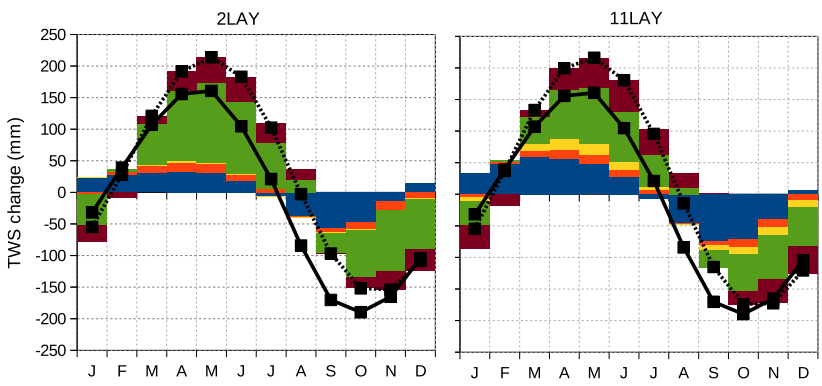

(c) Tapajos (ITA)
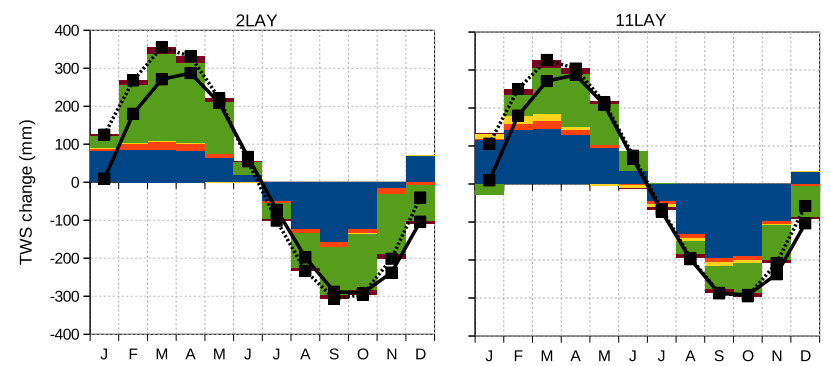

(e) Solimoes (SPO)
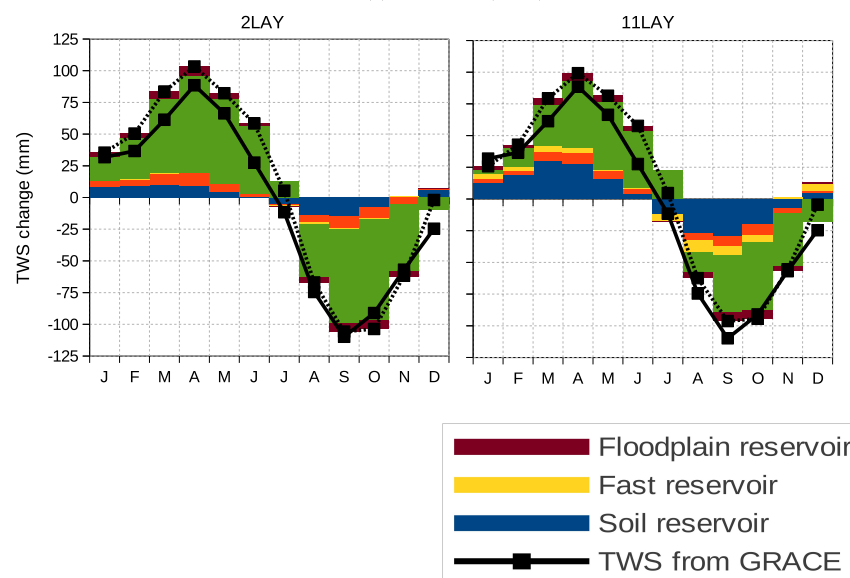

(b) Xingu (ALT)
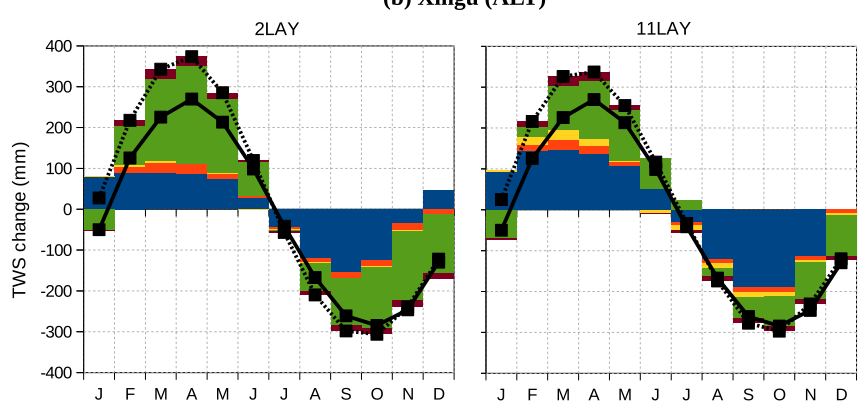

(d) Madeira (FVA)
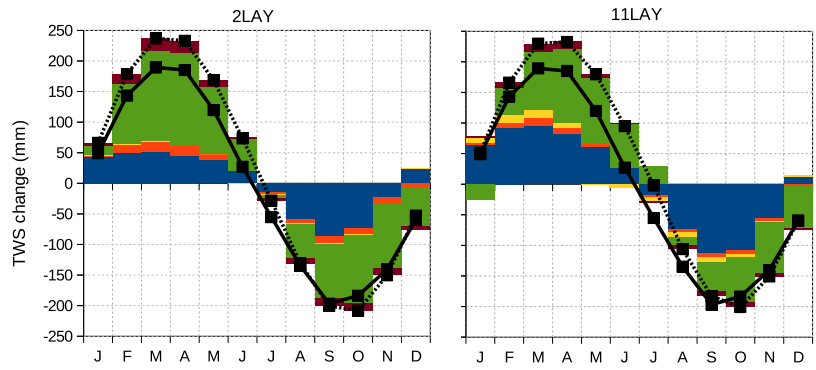

(f) Negro (SER)
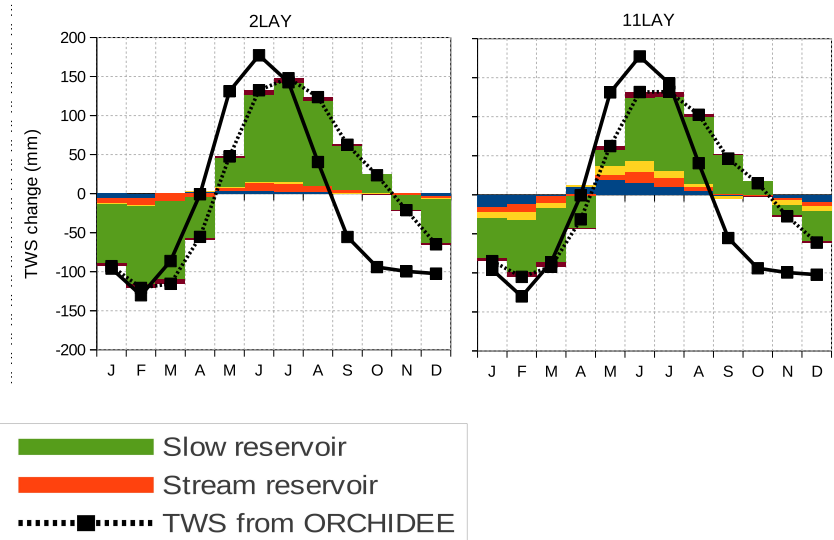

Figure 3. Monthly mean change of the water storage components $(\mathrm{mm})$ in the different water reservoirs of ORCHIDEE for simulations with the 2LAY (left) and the 11LAY (right), for the Amazon Basin and its sub-basins, averaged over the period 2003-2008. The thick black line represents the independent GRACE observation. The dotted black line is the sum of water storage across all the ORCHIDEE water reservoirs.

precipitation amplitude (see Sect. 4.1.1). This more pronounced TWS seasonal cycle in the south is well-represented by ORCHIDEE $\left(r^{2}>0.95\right)$. When the seasonal cycle is removed from the time series to reveal the interannual variability (IAV), the monthly correlation in the Xingu and Tapajós sub-basins strongly decreases $\left(0.46<r^{2}<0.68\right)$, suggesting that TWS IAV is difficult to capture (see Sect. 4.2.2). The simulated TWS amplitude is overestimated by between 10 and $30 \%$ in the three southern sub-basins, while the phase is well-captured by both soil hydrology schemes (difference between -9 to +8 days). TWS phase is overestimated (i.e., modeled TWS change occurs later than observed) in the southern floodplain areas of the Madeira sub-basin (see
Fig. 1c and d in the Supplement). The 11LAY systematically produces a better amplitude when compared to GRACE in the three sub-basins. The amplitude is particularly improved in the southern part of the Tapajós and the northern part of the Xingu sub-basins. Phase improvement is obtained with the 11LAY in the southern parts of these two southeastern sub-basins.

The western Solimões sub-basin has the lowest TWS amplitude, which is well-captured by ORCHIDEE - particularly by the 11LAY (Fig. 3e). The simulated TWS amplitude is overestimated by 6 to $16 \%$ when compared to GRACE data, but lower bias occurs with the 11LAY. The phase is wellcaptured by both soil hydrology schemes (bias lower than 

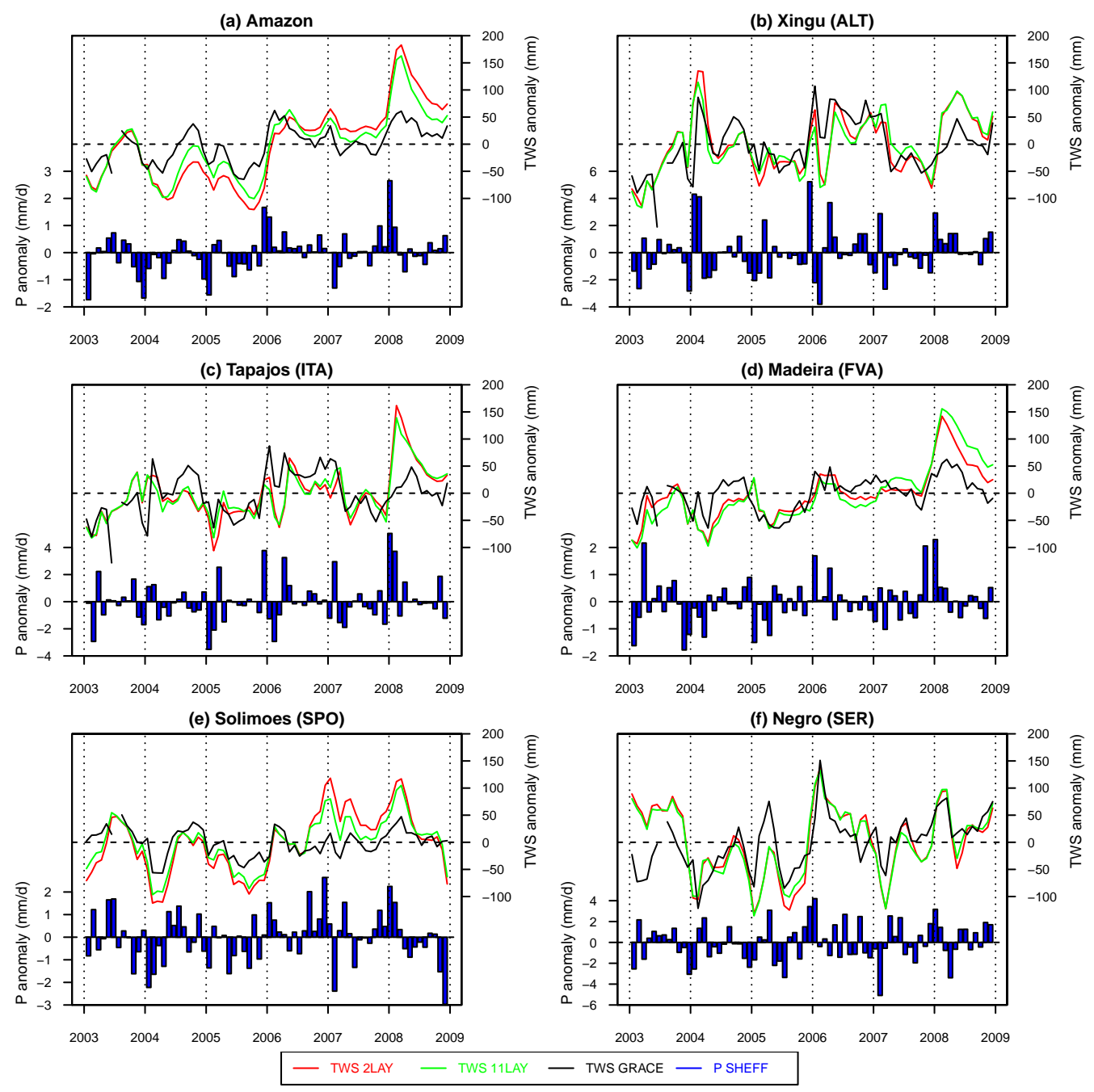

Figure 4. Interannual monthly variation of deseasonalized TWS (mm) from simulations (2LAY and 11LAY) compared to GRACE data, and Sheffield precipitation anomalies $\left(\mathrm{mm} \mathrm{d}^{-1}\right)$, for the Amazon Basin and its sub-basins, for the period 2003-2008.

3 days), except in the Andes where it is lagged by more than 25 days.

The simulated TWS anomalies in the northern Negro subbasin (Fig. 3f) exhibit correlations lower than 0.80 with GRACE, with a phase delay of about 1 month and an underestimation of the amplitude by up to $12 \%$ (11LAY). The amplitude is better captured by the 2LAY (bias of $0.4 \%$ ) compared to the 11LAY, whereas the bias in phase is reduced by 7 days with the 11LAY. For both soil hydrology schemes, the beginning of the storage period is delayed and the depletion exhibits too slow a decrease of stored water relative to the GRACE data.

The slow reservoir makes a large contribution to the TWS seasonal cycle over the northern and western sub-basin in both schemes, indicating that deep drainage is prevailing in these soils, in agreement with the results of Miguez-Macho and Fan (2012). The underestimated amplitude of the simulated TWS compared to GRACE over the Negro sub-basin could be explained by the negative bias in the precipitation forcing data set. Using satellite data products, Azarderakhsh et al. (2011) estimated from the water balance equation that precipitation over the western and northwestern regions could be underestimated by up to $3.2 \mathrm{~mm} \mathrm{~d}^{-1}$.

\subsubsection{Interannual variation (IAV)}

Deseasonalized TWS time series from GRACE data, over the Amazon Basin, reveals that the first 3 years of the period 2003-2008 are drier than the period average, while the last 3 years are wetter (Fig. 4a). This pattern agrees with Sheffield's precipitation anomaly variation. The TWS drop in GRACE during the intense drought of 2005 is due to the persistent negative monthly anomaly of precipitation during that year. The abrupt increase of rainfall anomaly at the end of 2005 and the persistent high positive anomaly in precipitation in January $2006\left(+1.25 \mathrm{~mm} \mathrm{~d}^{-1}\right)$ led to a TWS 
positive anomaly at the beginning of 2006 . The simulated TWS anomaly variation is closer to GRACE data with the 11LAY than with the 2LAY. During the 2005 drought, the too large a decrease in TWS simulated by both soil hydrology schemes is less pronounced with the 11LAY than the 2LAY (bias up to $-125 \mathrm{~mm}$ with GRACE). Overestimation of the wet anomaly at the beginning of 2008 is lower with the 11LAY $(+100 \mathrm{~mm})$.

Similar patterns occur in the Madeira sub-basin but with lower amplitude (Fig. 4d). The southeastern sub-basins (Xingu and Tapajós, Fig. 4b and c, respectively) exhibit higher abrupt transitions in TWS than the Madeira sub-basin during the 2003-2008 period. In the beginning of 2006, positive TWS anomalies (by up to $+100 \mathrm{~mm}$ ) are associated with intense precipitation events (up to $+5.0 \mathrm{~mm} \mathrm{~d}^{-1}$ ). These mainly occur at the beginning of 2004 and 2006 for the Xingu, and only in 2006 for the Tapajós. These events are not well-captured by either soil hydrology scheme, except for 2004 in the Xingu, with the 11LAY. Overall, the TWS increase in 2008 is systematically overestimated by ORCHIDEE in the southern sub-basins.

Low IAV of TWS measured by GRACE in the Solimões sub-basin (Fig. 4e) is overestimated by ORCHIDEE, and particularly by the $2 \mathrm{LAY}$ (up to $+100 \mathrm{~mm}$ ).

By contrast, high IAV of TWS is measured in the Negro sub-basin (Fig. 4f). When compared to GRACE data, ORCHIDEE estimates capture the intense dry event in early 2004 (TWS anomalies of $-100 \mathrm{~mm}$ ), but overestimate TWS decreases by more than $70 \mathrm{~mm}$ in 2005 and 2007.

Overall, the 11LAY provides similar TWS variation to the 2LAY but reduces the bias with GRACE in the Amazon subbasins.

\subsection{Spatial patterns and seasonal variations of ET and river discharge}

Both soil hydrology schemes simulate similar spatial patterns in annual ET over the basin (thus, only shown for the 11LAY in Fig. 5a), with the highest ET $\left(>3.5 \mathrm{~mm} \mathrm{~d}^{-1}\right)$ over the floodplains near the mouth of the Amazon, and along the Guaporé and Mamoré rivers in the southern region (see Fig. 1 for the location of the rivers). The 11LAY gives higher annual ET than the 2LAY in the southern regions (southern parts of the Madeira, Tapajós and Xingu sub-basins), in the Andes, near the mouth of the Amazon and in the northernmost part of the basin (between +0.1 and $+0.7 \mathrm{~mm} \mathrm{~d}^{-1}$, Fig. 5c), whereas very few regions exhibit higher annual ET with the 2LAY. Simulated ET is strongly underestimated when compared to MTE-ET, in the foothills of the eastern Andes $\left(>1.0 \mathrm{~mm} \mathrm{~d}^{-1}\right)$ and, too a lesser degree, in the center of the basin (between -0.4 and $-0.7 \mathrm{~mm} \mathrm{~d}^{-1}$, Fig. 5e). By contrast, simulated ET is overestimated in floodplain areas (more than $1.0 \mathrm{~mm} \mathrm{~d}^{-1}$ ). However, the MTE-ET product does not take into account floodplain areas and might underestimate actual ET. The largest difference in ET between the
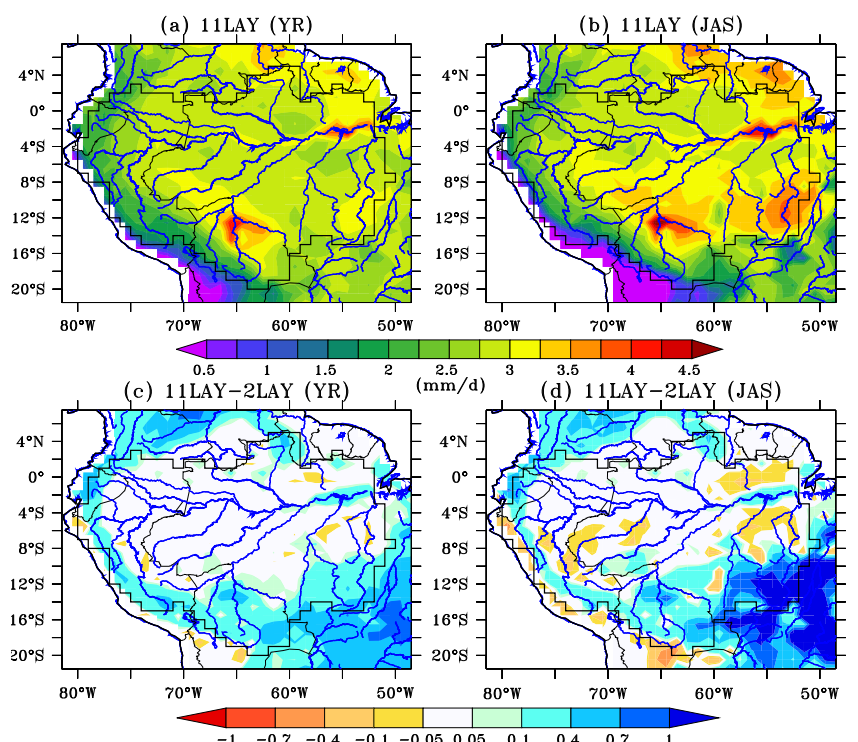

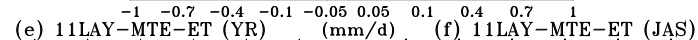

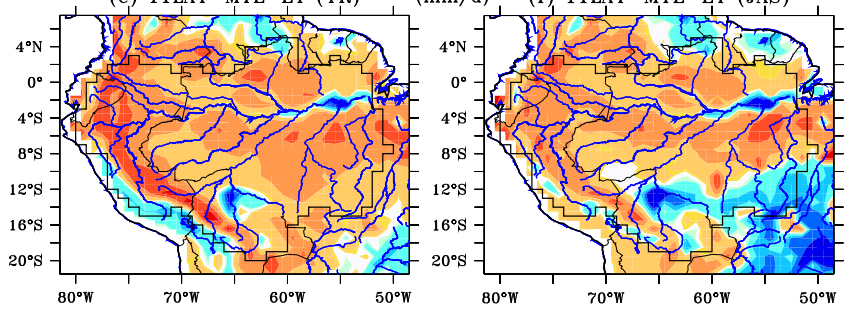

Figure 5. Mean ET $\left(\mathrm{mm} \mathrm{d}^{-1}\right)$ simulated by the 11LAY, averaged over (a) the complete year and (b) JAS, averaged over the period 1980-2008. Differences in simulated ET between the 11LAY and $(\mathbf{c}, \mathbf{d})$ the $2 \mathrm{LAY}$ and $(\mathbf{e}, \mathbf{f})$ the MTE-ET product.

two soil hydrology schemes occurs during the end of the dry season (JAS) in the southeast of the Amazon Basin (Fig. 5d). The southern part of the Xingu sub-basin exhibits a dryseason ET of about $4.0 \mathrm{~mm} \mathrm{~d}^{-1}$ with the 11LAY (Fig. 5b), more than $1.0 \mathrm{~mm} \mathrm{~d}^{-1}$ higher than with the 2LAY (Fig. 5d). The 11LAY overestimates the ET by $0.5 \mathrm{~mm} \mathrm{~d}^{-1}$ in this region when compared to MTE-ET (Fig. 5f). We will further investigate the effect of soil water storage parameterization on dry-season ET over the Xingu sub-basin in Sect. 4.4.

The dry-season ET increase simulated by the 11LAY is also apparent in the seasonal cycles of ET over the Xingu and Tapajós sub-basins in Fig. $6 \mathrm{~b}$ and c, respectively. In the other sub-basins, both soil hydrology schemes provide similar seasonal cycles in agreement with MTE-ET (Fig. 6d-f). However, a large spread in ET estimations exists in the subbasins (except in the Solimões), when the MTE-ET product is compared with GLEAM-ET, NTSG-ET and PKU-ET.

The 11LAY better simulates the river discharge than the 2LAY for the Amazon Basin and all its sub-basins (Fig. 6), except for the Solimões (see Table S3 in the Supplement). Improvement of estimated river discharge with the 11LAY is related to the better partitioning of total runoff into surface runoff and drainage and to the higher ET in the Xingu 
(a) Amazon (OBI)
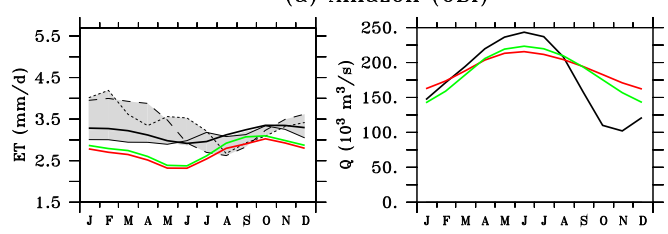

(c) Tapajos (ITA)
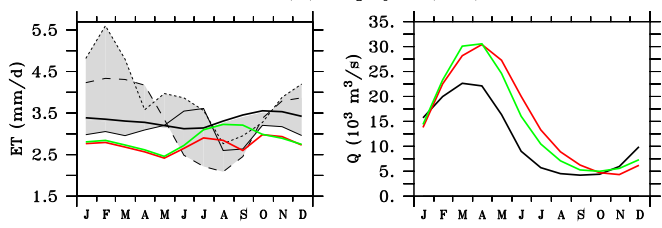

(e) Solimoes (SPO)
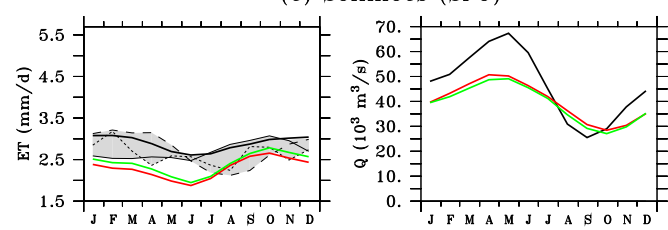

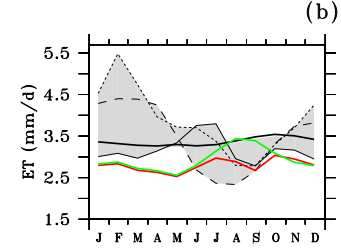

(b) Xingu (ALT)

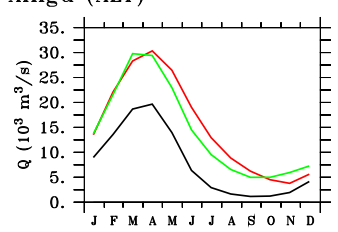

(d) Madeira (FVA)

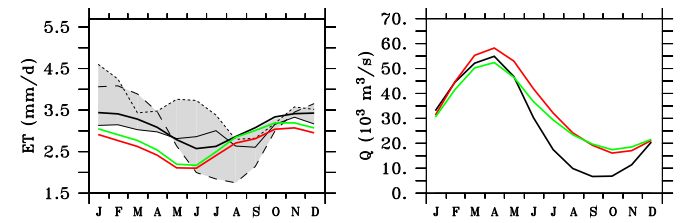

(f) Negro (SER)
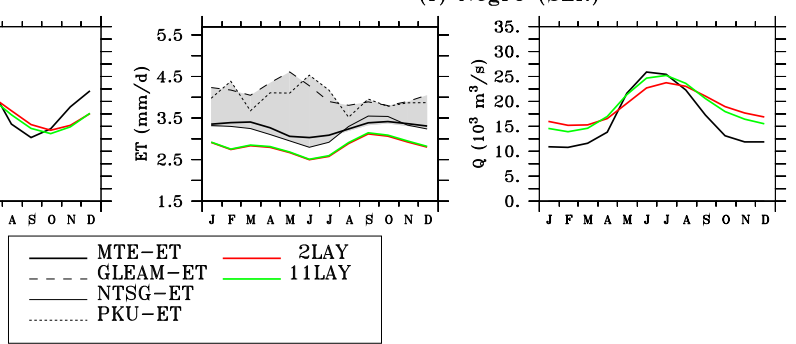

Figure 6. Monthly mean seasonal ET averaged over the different sub-basins $\left(\mathrm{mm} \mathrm{d}^{-1}\right)$ and river discharge at the gauging stations $\left(\mathrm{m}^{3} \mathrm{~s}^{-1}\right)$, from the 2LAY and 11LAY simulations compared to the observations, averaged over the period 1980-2008. The envelope (in gray) defines the spread existing between the four ET products for each month.

and Tapajós sub-basins leading to a better river discharge decrease during the recession limb (Fig. 6b and c, respectively).

\subsection{Dry-season evapotranspiration: case study of the Xingu sub-basin.}

The Xingu sub-basin, chosen as a case study in this section, is characterized by the existence of a marked dry season with low rainfall in JJA (Fig. 7a). During this season, the land surface receives less than $5 \%$ of the total annual precipitation, with monthly precipitation that does not exceed $2.0 \mathrm{~mm} \mathrm{~d}^{-1}$ (yellow bands in Fig. 7a). The dry season is between two transition periods in MAM (and SON), where precipitation falls (rises) abruptly, by about $6.0 \mathrm{~mm} \mathrm{~d}^{-1}$. The wet season occurs in DJF and brings an average $P$ of $10.6 \mathrm{~mm} \mathrm{~d}^{-1}$.

On average, over the 2003-2008 period, the MTE-ET product shows rather flat ET variation (Fig. 7b). Lowest MTE-ET mainly occurs after the wet season, whereas it is higher during the dry season, with the maximum occurring during the dry-to-wet transition period when precipitation and TWS anomalies increase (Fig. 7a and c, respectively). Both soil hydrology schemes simulate similar ET variation during the rainy seasons until the dry season onset (June and July). During these two months, they both estimate an ET increase, in response to the radiation increase and the high water demand from the vegetation; this demand could be met from the available water previously stored in the soil during the wet season. However, after the third consecutive dry month, the ET from the 11LAY continues to increase, while the 2LAY fails to sustain ET, which decreases in August and September (yellow bands in Fig. 7b). Interestingly, the largest decrease occurs during the years that have the longest dry seasons with low precipitation before and after JJA (2004 and 2007). This sensitivity of the soil hydrology scheme to the dry season length will be further studied in Sect. 4.5. The simulated ET is poorly correlated with the MTE-ET data set but the monthly correlation is higher with the 11LAY (0.49) than with the 2LAY (0.33). The low correlation can largely be attributed to the dry season ET simulation, as correlation is higher when the JJA period is removed from the time series $(0.63$ and 0.47 according to the 11LAY and $2 \mathrm{LAY}$, respectively). The ET increase during the dry season, relative to the annual value, is much higher in the simulations (up to $+0.85 \mathrm{~mm} \mathrm{~d}^{-1}$ ) than MTE-ET estimation (up to $\left.+0.20 \mathrm{~mm} \mathrm{~d}^{-1}\right)$.

In the wet season, the 2LAY produces an early maximum soil water storage (January), which remains constant until June (Fig. 7c), whereas the 11LAY produces higher anomalies, a longer period of soil water recharge (until March) and stores more water in the soil (see Fig. S2a in the Supplement). This stored water sustains dry-season ET. By contrast, the almost depleted 2LAY soil reservoir (see Fig. S2b in the 


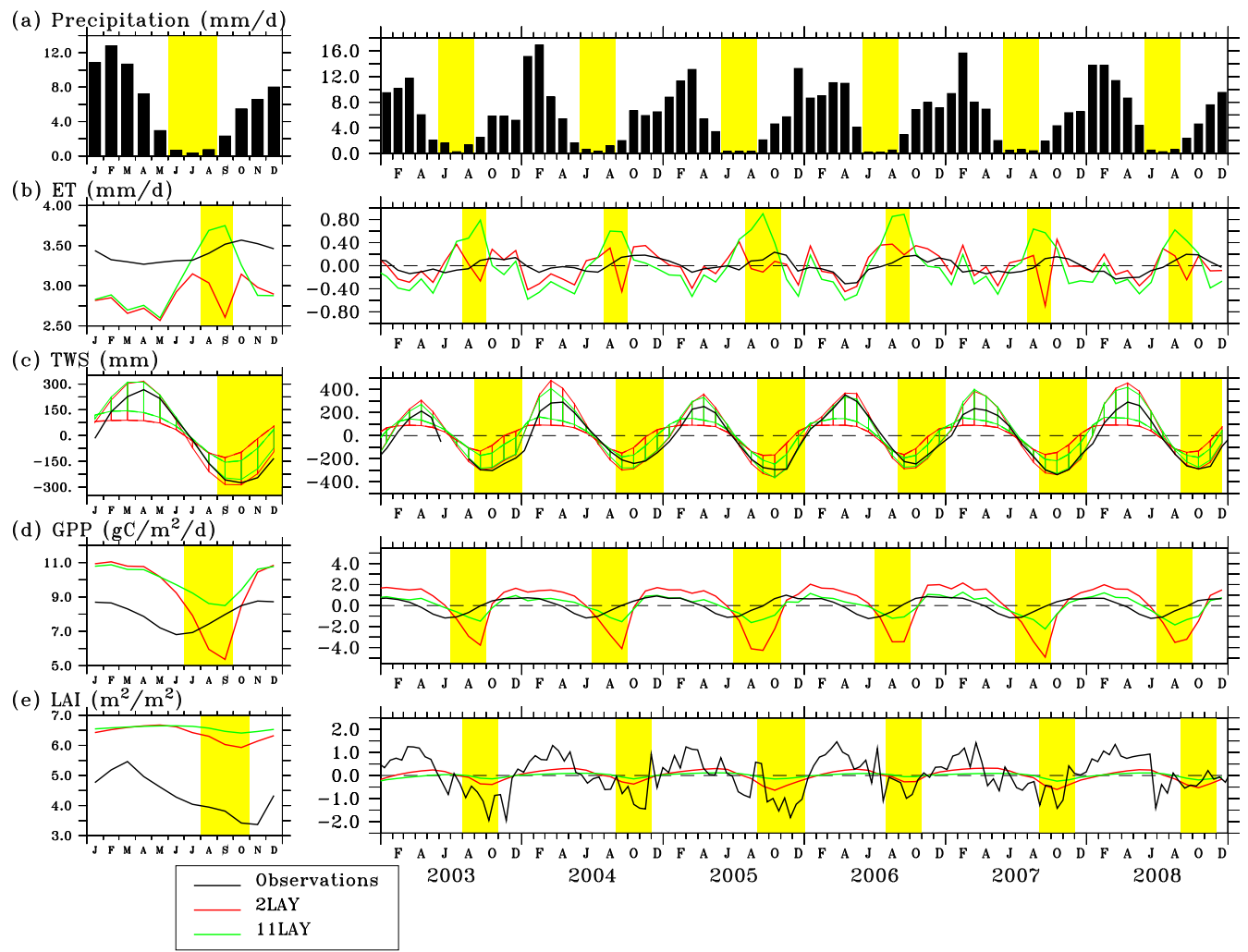

Figure 7. Seasonal cycle (left panels) and interannual monthly variation of anomaly (except precipitation) (right panels) in (a) precipitation $\left(\mathrm{mm} \mathrm{d}^{-1}\right)$, (b) ET $\left(\mathrm{mm} \mathrm{d}^{-1}\right)$, (c) TWS change (mm) (d) GPP $\left(\mathrm{g} \mathrm{C}^{-2} \mathrm{~d}^{-1}\right)$ and (e) LAI $\left(\mathrm{m}^{2} \mathrm{~m}^{-2}\right)$ averaged over the Xingu sub-basin, from simulations (2LAY and 11LAY) and observations, for the period 2003-2008. For anomaly computation, the mean value over the period considered was subtracted from each monthly value of the variable. The yellow band indicates the dry season (in a) and the period during which the difference in results between the 2LAY and 11LAY is high (in b to e). The shaded area (red and green in $\mathbf{c}$ ) corresponds to the simulated anomaly of water stored in reservoirs other than the soil reservoir (dotted red and green lines in c).

Supplement for the end of the dry season) fails to sustain ET during the 3 consecutive dry months (JAS). The yellow bands in Fig. 7a-c, show the propagation of the dry-season precipitation deficit over time through the hydrological system, leading to phase lags in ET and TWS, already described by McNab (1989) and Entekhabi et al. (1996).

During the wet season, monthly GPP simulated by both soil hydrology schemes is similar (Fig. 7d). The 2LAY overestimates GPP anomalies, while the 11LAY captures the MTE-GPP variation. During the beginning of the dry season, MTE-GPP decrease is overestimated by ORCHIDEE. Both soil hydrology schemes simulate a delay of 3 months in GPP minima during the dry season. Lower drought stress with the 11LAY leads to a less severe decrease in GPP compared to the 2LAY $\left(-1 \mathrm{gC} \mathrm{m}^{-2} \mathrm{~d}^{-1}\right.$ and $-4 \mathrm{gC} \mathrm{m}^{-2} \mathrm{~d}^{-1}$ in September compared to the mean annual value, for the 11LAY and 2LAY, respectively) and to a better agreement with MTEGPP (yellow bands in Fig. 7d). The LAI decrease is consequently slightly less pronounced with the 11LAY $(-0.1)$ when compared to the 2LAY (-0.3) during the dry season (yellow bands in Fig. 7e). However, both soil hydrology schemes display smaller monthly anomalies of LAI than the
GIMMS data. This may suggest a lack of realism in representing the interactions between hydrology and phenology in ORCHIDEE. Further site-level simulations should be performed - i.e., comparing simulated fluxes to flux tower measurements to identify the missing modeling processes in ORCHIDEE, such as leaf litterfall dynamics (De Weirdt et al., 2012). However, estimates of the LAI variation of tropical forest from remote sensing data are highly inaccurate (see Fig. 9d in Garrigues et al., 2008).

\subsection{Evapotranspiration sensitivity to dry season length}

The 11LAY scheme simulates more ET than the 2LAY during the dry season, over the Amazon Basin. To test the sensitivity of the two soil hydrology schemes to dry season duration, we define the dry-season length (DSL) as the mean annual number of months with $P<2.0 \mathrm{~mm} \mathrm{~d}^{-1}$ over the time period 1980-2008. Using an alternative definition which takes into account only consecutive months with $P<$ $2.0 \mathrm{~mm} \mathrm{~d}^{-1}$ does not change the results. Representing ET variation from the two soil hydrology schemes as a function of the DSL over the whole Amazon Basin (Fig. 8a) shows 

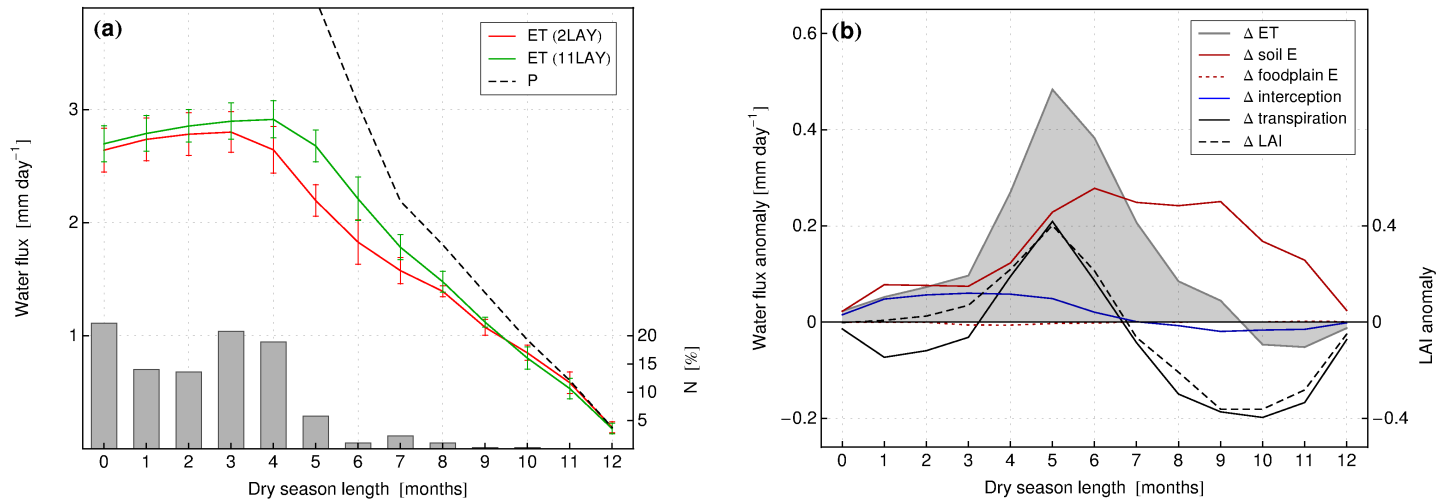

Figure 8. (a) Mean annual ET $\left(\mathrm{mm} \mathrm{d}^{-1}\right)$ from simulations (2LAY and 11LAY) and Sheffield precipitation (mm $\left.\mathrm{d}^{-1}\right)$ over the Amazon Basin as functions of the dry season length (DSL in months, see Sect. 4.5 for its definition). Solid lines represent the mean ET and spread (1 SD) within moving bins of DSL of 1 month, according to the two simulations. The values are obtained from individual grid cells of the simulated domain. Density of grid cells $(N$ in \%) associated with each DSL value is given in the histogram. (b) Differences of mean annual ET $\left(\mathrm{mm} \mathrm{d}^{-1}\right)$, its components $\left(\mathrm{mm} \mathrm{d}^{-1}\right)$ and LAI $\left(\mathrm{m}^{2} \mathrm{~m}^{-2}\right)$ between the 11LAY and 2LAY according to the DSL, over the Amazon Basin, for the period 1980-2008.

that the maximum ET is simulated by ORCHIDEE when the DSL is 4 months. A DSL $\leq 4$ months applies to $85 \%$ of the total grid cells over the Amazon Basin. When DSL is between 4 and 7 months, ET decrease is more pronounced with the 2LAY than the 11LAY. The maximum difference between the two soil hydrology schemes is with a DSL of 5 months $\left(+0.45 \mathrm{~mm} \mathrm{~d}^{-1}\right.$, Fig. 8 b), which applies to only $5 \%$ of the total grid cells. For longer dry seasons (DSL $\geq 7$ months, for $8 \%$ of the total grid cells), the impact of soil hydrology scheme on ET is negligible.

Figure 8b highlights the differences in ET components, which contribute to the total ET, and LAI differences between the two soil hydrology schemes when DSL increases. For short dry seasons (DSL $<4$ months), the 11LAY estimates higher bare soil evaporation $\left(+0.07 \mathrm{~mm} \mathrm{~d}^{-1}\right)$ when compared to the $2 \mathrm{LAY}$. The $11 \mathrm{LAY}$ water content in the very thin first layer is directly evaporated to satisfy the climatic demand. By contrast, the resistance to bare soil evaporation in the superficial layer of the 2LAY limits the water exchange. The 11LAY transpiration is consequently smaller than that estimated by the 2LAY. Evaporation of water intercepted by the canopy is the main ET component $\left(+0.05 \mathrm{~mm} \mathrm{~d}^{-1}\right)$ contributing to ET increase with the 11LAY when DSL takes values of less than 4 months. For a longer dry season (4 and 5 months), bare soil evaporation continues to increase (up to $+0.25 \mathrm{~mm} \mathrm{~d}^{-1}$ ) and lower drought stress with the 11LAY (as reported in Sect. 4.4) leads to enhanced transpiration of the same magnitude, increasing canopy leaf area (up to +0.4 of LAI). For extreme DSL (DSL $\geq 6$ months), neither of the soil hydrology schemes could supply ET because this period of drought stress is too long. Under these conditions, transpiration (and LAI) difference between the two soil hydrology schemes decreases. Bare soil evaporation is still higher with the 11LAY (around $+0.25 \mathrm{~mm} \mathrm{~d}^{-1}$ ), whereas difference in evaporation by rainfall interception decreases with decreasing LAI difference. The higher water-holding capacity of the 11LAY compared to the 2LAY no longer has any effect on ET supply. Moreover, the drainage flux, which is prescribed in the deepest soil layer of the 11LAY, decreases the residence time of the water in the soil column compared to the 2LAY where drainage flux does not exist. Drought stress consequently becomes higher in the 11LAY, leading to lower transpiration (up to $-0.2 \mathrm{~mm} \mathrm{~d}^{-1}$ ) and lower LAI (up to -0.4 ). For DSL $\geq 10$ months, the difference in bare soil evaporation between soil hydrology schemes decreases and total ET then becomes lower with the 11LAY than with the 2LAY.

\section{Conclusions}

Over the entire Amazon Basin, and for its sub-basins, differences in water budget components simulated by the two soil hydrology schemes are small. When compared with observations, the 11LAY slightly reduces the bias in the simulation of ET and $Q$ in the sub-basins, but because ET observation uncertainties are of the same magnitude as the misfit between either of the schemes and the observations, neither scheme can be ruled out.

Differences between the 2LAY and the 11LAY parameterizations are more significant in the Xingu and Tapajós subbasins that are exposed to a more marked dry season. The greater soil water-holding capacity in the 11LAY sustains ET in the Xingu, over the 3 consecutive dry months. In contrast, after 2 dry months, the $2 \mathrm{LAY}$ strongly reduces ET. This greater dry-season ET estimated by the 11LAY leads to a better representation of GPP and prevents a reduction of LAI during the dry season. 
Besides, in most of the sub-basins of the Amazon, the 11LAY does improve the simulation of TWS anomalies. The physical distinction between surface runoff and drainage in this scheme leads to a fraction of drainage to total runoff of $69 \%$ that compares well with the estimates of Mortatti et al. (1997). This is much smaller than the arbitrary fraction of $95 \%$ with the 2LAY. As a result, the 11LAY stores less water in the slow (groundwater) reservoir of the routing scheme, with a contribution of subsurface water to TWS over the Amazon Basin (71\%) that is consistent with the modeling results of Pokhrel et al. (2013) and Niu et al. (2007).

The results from this study also emphasize the need to improve the representation of the drought-stress impact on carbon fluxes, transpiration and phenology. Additional comparisons of site-level simulations with the results of artificial droughting experiments (see Meir and Ian Woodward, 2010) and flux tower measurements across the basin would help to improve the formulation of the main processes involved in drought stress. More attention should be also paid to the soil depth, which was fixed at $2 \mathrm{~m}$ for the entire basin in both soil hydrology schemes. Roots can be present much deeper than 2 m (Nepstad et al., 1994; Canadell et al., 1996), which feeds back on climate (Kleidon and Heimann, 2000). Several modeling studies have concluded that deep soils and deep roots are needed to realistically represent ET and GPP in Amazonian forests (e.g., Baker et al., 2008; Verbeeck et al., 2011). In particular, Verbeeck et al. (2011) showed that the soil depth had a significant effect on the seasonal cycle of water fluxes with the $2 \mathrm{LAY}$. We tested a soil depth of $8 \mathrm{~m}$ in the 11LAY but found only a negligible effect owing to the high soil water-holding capacity in that scheme.

Overall, this study highlights the effect of dry-season length on ET, vegetation phenology and GPP, and their sensitivity to soil hydrology over the Amazon Basin. The multilayer diffusion soil scheme is shown to be the most reliable option for further investigating the potential feedbacks between surface hydrology and precipitation, especially in southern Amazonia, where low flows could severely decrease in the future (Guimberteau et al., 2013).

\section{Code availability}

The version of the ORCHIDEE model used for this study is Trunk.rev1311. The source code of the ORCHIDEE model can be obtained upon request (see http://labex.ipsl. fr/orchidee/index.php/contact). Documentation on the code including scientific and technical aspects, is available here: https://forge.ipsl.jussieu.fr/orchidee/wiki/Documentation.

\section{The Supplement related to this article is available online at doi:10.5194/gmd-7-1115-2014-supplement.}

Acknowledgements. This work was financially supported by the EU-FP7 AMAZALERT (Raising the alert about critical feedbacks between climate and long-term land-use change in the Amazon) project. We acknowledge the ORE HYBAM team, who made available their precipitation and river flow data sets for the Amazon Basin (http://www.ore-hybam.org). We gratefully acknowledge Martin Jung for access to the ET and GPP data set and Bertrand Decharme for providing Sheffield's forcing data set including precipitation correction by GPCC. GRACE land data (available at http://grace.jpl.nasa.gov) processing algorithms were provided by Sean Swenson, and supported by the NASA MEaSUREs Program. Simulations with ORCHIDEE were performed using computational facilities of the Institut du Développement et des Ressources en Informatique Scientifique (IDRIS, CNRS, France). Grateful acknowledgement for proofreading and correcting the English edition goes to John Gash.

Edited by: C. Sierra

\section{References}

Abramopoulos, F., Rosenzweig, C., and Choudhury, B.: Improved ground hydrology calculations for global climate models (GCMs): Soil water movement and evapotranspiration, J. Climate, 1, 921-941, 1988.

Azarderakhsh, M., Rossow, W., Papa, F., Norouzi, H., and Khanbilvardi, R.: Diagnosing water variations within the Amazon basin using satellite data, J. Geophys. Res.-Atmos., 116, D24107, doi:10.1029/2011JD015997, 2011.

Baker, I., Prihodko, L., Denning, A., Goulden, M., Miller, S., and Da Rocha, H.: Seasonal drought stress in the Amazon: Reconciling models and observations, J. Geophys. Res.-Biogeo., 113, G00B01, doi:10.1029/2007JG000644, 2008.

Ball, J., Woodrow, I., and Berry, J.: A model predicting stomatal conductance and its contribution to the control of photosynthesis under different environmental conditions, in: Prog. Photosynthesis Res. Proc. Int. Congress 7th, Providence. 10-15 August 1986 , Vol 4. Kluwer, Boston., 221-224, 1987.

Becker, M., Meyssignac, B., Xavier, L., Cazenave, A., Alkama, R., and Decharme, B.: Past terrestrial water storage (19802008) in the Amazon Basin reconstructed from GRACE and in situ river gauging data, Hydrol. Earth Syst. Sci., 15, 533-546, doi:10.5194/hess-15-533-2011, 2011.

Beighley, R., Eggert, K., Dunne, T., He, Y., Gummadi, V., and Verdin, K.: Simulating hydrologic and hydraulic processes throughout the Amazon River Basin, Hydrol. Process., 23, 1221 1235, 2009.

Belward, A., Estes, J., and Kline, K.: The IGBP-DIS global 1-km land-cover data set DISCover: A project overview, Photogramm. Eng. Rem. S., 65, 1013-1020, 1999.

Bettadpur, S.: Level-2 Gravity Field Product User Handbook, GRACE 327-734, The GRACE Project, Cent. for Space Res., Univ. of Tex. at Austin, Austin, Tex., 2012.

Beven, K.: Infiltration into a class of vertically non-uniform soils, Hydrol. Sci. J., 29, 425-434, 1984.

Beven, K. and Germann, P.: Macropores and water flow in soils, Water Resour. Res., 18, 1311-1325, doi:10.1029/WR018i005p01311, 1982. 
Boberg, F. and Christensen, J. H.: Overestimation of Mediterranean summer temperature projections due to model deficiencies, Nature Clim. Change, 2, 433-436, 2012.

Boone, A., Masson, V., Meyers, T., and Noilhan, J.: The influence of the inclusion of soil freezing on simulations by a soil-vegetationatmosphere transfer scheme, J. Appl. Meteorol., 39, 1544-1569, 2000.

Callede, J., Ronchail, J., Guyot, J., and Oliveira, E.: Déboisement amazonien: son influence sur le débit de l'Amazone à Óbidos (Brésil), Rev. Sci. Eau, 21, 59-72, 2008.

Campoy, A., Ducharne, A., Cheruy, F., Hourdin, F., Polcher, J., and Dupont, J.: Influence of soil bottom hydrological conditions on land surface fluxes and climate in a general circulation model, J. Geophys. Res.-Atmos., 118, 10725-10739, doi:10.1002/jgrd.50627, 2013.

Canadell, J., Jackson, R., Ehleringer, J., Mooney, H., Sala, O., and Schulze, E.-D.: Maximum rooting depth of vegetation types at the global scale, Oecologia, 108, 583-595, 1996.

Carsel, R. and Parrish, R.: Developing joint probability distributions of soil water retention characteristics, Water Resour. Res., 24, 755-769, doi:10.1029/WR024i005p00755, 1988.

Chen, F., Janjić, Z., and Mitchell, K.: Impact of atmospheric surface-layer parameterizations in the new land-surface scheme of the NCEP mesoscale Eta model, Bound.-Lay. Meteorol., 85, 391-421, 1997.

Chen, J., Wilson, C., Tapley, B., Yang, Z., and Niu, G.: 2005 drought event in the Amazon River basin as measured by GRACE and estimated by climate models, J. Geophys. Res.-Sol Ea., 114, B05404, doi:10.1029/2008JB006056, 2009.

Chen, J., Wilson, C., and Tapley, B.: The 2009 exceptional Amazon flood and interannual terrestrial water storage change observed by GRACE, Water Resour. Res., 46, W12526, doi:10.1029/2010WR009383, 2010.

Cheruy, F., Campoy, A., Dupont, J.-C., Ducharne, A., Hourdin, F., Haeffelin, M., Chiriaco, M., and Idelkadi, A.: Combined influence of atmospheric physics and soil hydrology on the simulated meteorology at the SIRTA atmospheric observatory, Clim. Dynam., 40, 2251-2269, 2013.

Cochonneau, G., Sondag, F., Guyot, J., Geraldo, B., Filizola, N., Fraizy, P., Laraque, A., Magat, P., Martinez, J., Noriega, L., Oliveira, E., Ordonez, J., Pombosa, R., Seyler, F., Sidgwick, J., and Vauchel, P.: The Environmental Observation and Research project, ORE HYBAM, and the rivers of the Amazon basin, 4450, IAHS Press, 2006.

Coe, M., Costa, M., and Howard, E.: Simulating the surface waters of the Amazon River basin: impacts of new river geomorphic and flow parameterizations, Hydrol. Process., 22, 2542-2553, 2007.

Collatz, G. J., Ribas-Carbo, M., and Berry, J.: Coupled photosynthesis-stomatal conductance model for leaves of $\mathrm{C} 4$ plants, Funct. Plant Biol., 19, 519-538, 1992.

Cox, P., Betts, R., Bunton, C., Essery, R., Rowntree, P., and Smith, J.: The impact of new land surface physics on the GCM simulation of climate and climate sensitivity, Clim. Dynam., 15, 183203, 1999.

Crowley, J. W., Mitrovica, J. X., Bailey, R. C., Tamisiea, M. E., and Davis, J. L.: Annual variations in water storage and precipitation in the Amazon Basin, J. Geodesy, 82, 9-13, 2008.

Dai, Y., Zeng, X., Dickinson, R. E., Baker, I., Bonan, G. B., Bosilovich, M. G., Denning, A. S., Dirmeyer, P. A., Houser, P. R.,
Niu, G., Oleson, K. W., Schlosser, C. A., and Zong-Liang, Y.: The common land model, Bull. Am. Meteorol. Soc., 84, 10131023, 2003.

Da Rocha, H., Manzi, O., and Shuttleworth, J.: Evapotranspiration, Geoph. Monog. Series, 186, 261-272, 2009a.

Da Rocha, H. R., Manzi, A. O., Cabral, O. M., Miller, S. D., Goulden, M. L., Saleska, S. R., R-Coupe, N., Wofsy, S. C., Borma, L. S., Artaxo, P., Vourlitis, G., Nogueira, J. S., Cardoso, F. L., Nobre, A. D., Kruijt, B., Freitas, H. C., von Randow, C., Aguiar, R. G., and Maia, J. F.: Patterns of water and heat flux across a biome gradient from tropical forest to savanna in Brazil, J. Geophys. Res.-Biogeo., 114, G00B12, doi:10.1029/2007JG000640, 2009b.

Decharme, B. and Douville, H.: Uncertainties in the GSWP-2 precipitation forcing and their impacts on regional and global hydrological simulations, Clim. Dynam., 27, 695-713, 2006.

Decharme, B., Douville, H., Prigent, C., Papa, F., and Aires, F.: A new river flooding scheme for global climate applications: Offline evaluation over South America, J. Geophys. Res.-Atmos., 113, D11110, doi:10.1029/2007JD009376, 2008.

Decharme, B., Boone, A., Delire, C., and Noilhan, J.: Local evaluation of the Interaction between Soil Biosphere Atmosphere soil multilayer diffusion scheme using four pedotransfer functions, J. Geophys. Res.-Atmos., 116, D20126, doi:10.1029/2011JD016002, 2011.

De Rosnay, P. and Polcher, J.: Modelling root water uptake in a complex land surface scheme coupled to a GCM, Hydrol. Earth Syst. Sci., 2, 239-255, doi:10.5194/hess-2-239-1998, 1998.

De Rosnay, P., Bruen, M., and Polcher, J.: Sensitivity of surface fluxes to the number of layers in the soil model used in GCMs, Geophys. Res. Lett., 27, 3329-3332, doi:10.1029/2000GL011574, 2000.

De Rosnay, P., Polcher, J., Bruen, M., and Laval, K.: Impact of a physically based soil water flow and soil-plant interaction representation for modeling large-scale land surface processes, J. Geophys. Res.-Atmos., 107, 4118, doi:10.1029/2001JD000634, 2002.

De Rosnay, P., Drusch, M., Vasiljevic, D., Balsamo, G., Albergel, C., and Isaksen, L.: A simplified Extended Kalman Filter for the global operational soil moisture analysis at ECMWF, Q. J. Roy. Meteor. Soc., 139, 1199-1213, 2013.

De Weirdt, M., Verbeeck, H., Maignan, F., Peylin, P., Poulter, B., Bonal, D., Ciais, P., and Steppe, K.: Seasonal leaf dynamics for tropical evergreen forests in a process-based global ecosystem model, Geosci. Model Dev., 5, 1091-1108, doi:10.5194/gmd-51091-2012, 2012.

D'Orgeval, T.: Impact du changement climatique sur le cycle de l'eau en Afrique de l'Ouest: modélisation et incertitudes, Ph.D. thesis, Université Paris VI, 2006.

D’Orgeval, T., Polcher, J., and de Rosnay, P.: Sensitivity of the West African hydrological cycle in ORCHIDEE to infiltration processes, Hydrol. Earth Syst. Sci., 12, 1387-1401, doi:10.5194/hess-12-1387-2008, 2008.

Douville, H.: Relative contribution of soil moisture and snow mass to seasonal climate predictability: a pilot study, Clim. Dynam., 34, 797-818, 2010.

Draper, C., Mahfouf, J.-F., Calvet, J.-C., Martin, E., and Wagner, W.: Assimilation of ASCAT near-surface soil moisture into the 
SIM hydrological model over France, Hydrol. Earth Syst. Sci., 15, 3829-3841, doi:10.5194/hess-15-3829-2011, 2011.

Ducharne, A., Laval, K., and Polcher, J.: Sensitivity of the hydrological cycle to the parametrization of soil hydrology in a GCM, Clim. Dynam., 14, 307-327, 1998.

Ducharne, A., Golaz, C., Leblois, E., Laval, K., Polcher, J., Ledoux, E., and de Marsily, G.: Development of a high resolution runoff routing model, calibration and application to assess runoff from the LMD GCM, J. Hydrol., 280, 207-228, 2003.

Ducoudré, N., Laval, K., and Perrier, A.: SECHIBA, a new set of parameterizations of the hydrologic exchanges at the land atmosphere interface within the LMD atmospheric global circulation model, J. Climate, 6, 248-273, 1993.

Dunne, T. and Black, R. D.: An experimental investigation of runoff production in permeable soils, Water Resour. Res., 6, 478-490, doi:10.1029/WR006i002p00478, 1970.

Entekhabi, D., Rodriguez-Iturbe, I., and Castelli, F.: Mutual interaction of soil moisture state and atmospheric processes, J. Hydrol., 184, 3-17, 1996.

Fan, Y. and Miguez-Macho, G.: Potential groundwater contribution to Amazon evapotranspiration, Hydrol. Earth Syst. Sci., 14, 2039-2056, doi:10.5194/hess-14-2039-2010, 2010.

FAO: Soil map of the world, scale 1:5000000, Tech. rep., United Nations, volumes I-X, United Nations Educationnal, Scientific and Cultural Organization, Paris, 1978.

Farquhar, G., von Caemmerer, S. v., and Berry, J.: A biochemical model of photosynthetic $\mathrm{CO}_{2}$ assimilation in leaves of $\mathrm{C} 3$ species, Planta, 149, 78-90, 1980.

Feddes, R., Hoff, H., Bruen, M., Dawson, T., De Rosnay, P., Dirmeyer, P., Jackson, R., Kabat, P., Kleidon, A., Lilly, A., and Pitman, A.: Modeling root water uptake in hydrological and climate models, Bull. Am. Meteorol. Soc., 82, 2797-2810, 2001.

Frappart, F., Ramillien, G., and Ronchail, J.: Changes in terrestrial water storage versus rainfall and discharges in the Amazon basin, Int. J. Climatol., 33, 3029-3046, 2013.

Garrigues, S., Lacaze, R., Baret, F., Morisette, J., Weiss, M., Nickeson, J., Fernandes, R., Plummer, S., Shabanov, N., Myneni, R., Knyazikhin, Y., and Yang, W.: Validation and intercomparison of global Leaf Area Index products derived from remote sensing data, J. Geophys. Res.-Biogeo., 113, G02028, doi:10.1029/2007JG000635, 2008.

Gatti, L. V., Gloor, M., Miller, J. B., Doughty, C. E., Malhi, Y., Domingues, L. G., Basso, L. S., Martinewski, A., Correia, C. S. C., Borges, V. F., Freitas, S., Braz, R., Anderson, L. O., Rocha, H., Grace, J., Phillips, O. L., and Lloyd, J.: Drought sensitivity of Amazonian carbon balance revealed by atmospheric measurements, Nature, 506, 76-80, 2014.

Gouttevin, I., Krinner, G., Ciais, P., Polcher, J., and Legout, C.: Multi-scale validation of a new soil freezing scheme for a landsurface model with physically-based hydrology, The Cryosphere, 6, 407-430, doi:10.5194/tc-6-407-2012, 2012.

Green, W. H. and Ampt, G.: Studies on soil physics, 1. The flow of air and water through soils, J. Agr. Sci., 4, 1-24, 1911.

Guillod, B. P., Davin, E. L., Kündig, C., Smiatek, G., and Seneviratne, S. I.: Impact of soil map specifications for European climate simulations, Clim. Dynam., 40, 123-141, 2013.

Guimberteau, M., Drapeau, G., Ronchail, J., Sultan, B., Polcher, J., Martinez, J.-M., Prigent, C., Guyot, J.-L., Cochonneau, G., Espinoza, J. C., Filizola, N., Fraizy, P., Lavado, W., De Oliveira,
E., Pombosa, R., Noriega, L., and Vauchel, P.: Discharge simulation in the sub-basins of the Amazon using ORCHIDEE forced by new datasets, Hydrol. Earth Syst. Sci., 16, 911-935, doi:10.5194/hess-16-911-2012, 2012a.

Guimberteau, M., Perrier, A., Laval, K., and Polcher, J.: A comprehensive approach to analyze discrepancies between land surface models and in-situ measurements: a case study over US and Illinois with SECHIBA forced by NLDAS, Hydrol. Earth Syst. Sc., 16, 3973-3988, 2012b.

Guimberteau, M., Ronchail, J., Espinoza, J., Lengaigne, M., Sultan, B., Polcher, J., Drapeau, G., Guyot, J., Ducharne, A., and Ciais, P.: Future changes in precipitation and impacts on extreme streamflow over Amazonian sub-basins, Environ. Res. Lett., 8, 014035, doi:10.1088/1748-9326/8/1/014035, 2013.

Gulden, L., Rosero, E., Yang, Z., Rodell, M., Jackson, C., Niu, G., Yeh, P., and Famiglietti, J.: Improving land-surface model hydrology: Is an explicit aquifer model better than a deeper soil profile?, Geophys. Res. Lett., 34, 9402, doi:10.1029/2007GL029804, 2007.

Gutmann, E. and Small, E.: The effect of soil hydraulic properties vs. soil texture in land surface models, Geophys. Res. Lett., 32, L02402, doi:10.1029/2004GL021843, 2005.

Hagemann, S. and Dumenil, L.: A parameterization of the lateral waterflow for the global scale, Clim. Dynam., 14, 17-31, 1998.

Hagemann, S. and Stacke, T.: Impact of the soil hydrology scheme on simulated soil moisture memory, Clim. Dynam., submitted, 2014.

Horton, R. E.: The role of infiltration in the hydrologic cycle, Trans. Am. Geophys. Union, 14, 446-460, 1933.

Huffman, G., Adler, R., Morrissey, M., Bolvin, D., Curtis, S., Joyce, R., McGavock, B., and Susskind, J.: Global precipitation at onedegree daily resolution from multisatellite observations, J. Hydrometeorol., 2, 36-50, 2001.

Huffman, G., Bolvin, D., Nelkin, E., Wolff, D., Adler, R., Gu, G., Hong, Y., Bowman, K., and Stocker, E.: The TRMM multisatellite precipitation analysis (TMPA): Quasi-global, multiyear, combined-sensor precipitation estimates at fine scales, J. Hydrometeorol., 8, 38-55, 2007.

Jung, M., Reichstein, M., Ciais, P., Seneviratne, S., Sheffield, J., Goulden, M., Bonan, G., Cescatti, A., Chen, J., De Jeu, R., Johannes Dolman, A., Eugster, W., Gerten, D., Gianelle, D., Gobron, N., Heinke, J., Kimball, J., Law, B. E., Montagnani, L., Mu, Q., Mueller, B., Oleson, K., Papale, D., Richardson, A. D., Roupsard, O., Running, S., Tomelleri, E., Viovy, N., Weber, U., Williams, C., Wood, E., Zaehle, S., and Zhang, K.: Recent decline in the global land evapotranspiration trend due to limited moisture supply, Nature, 467, 951-954, 2010.

Jung, M., Reichstein, M., Margolis, H., Cescatti, A., Richardson, A., Arain, M., Arneth, A., Bernhofer, C., Bonal, D., Chen, J., Gianelle, D., Gobron, N., Kiely, G., Kutsch, W., Lasslop, G., Law, B. E., Lindroth, A., Merbold, L., Montagnani, L., Moors, E. J., Papale, D., Sottocornola, M., Vaccari, F., and Williams, C.: Global patterns of land-atmosphere fluxes of carbon dioxide, latent heat, and sensible heat derived from eddy covariance, satellite, and meteorological observations, J. Geophys. Res.-Biogeo., 116, G00J07, doi:10.1029/2010JG001566, 2011.

Keller, M., Alencar, A., Asner, G. P., Braswell, B., Bustamante, M. Davidson, E., Feldpausch, T., Fernandes, E., Goulden, M., Kabat, P., Kruijt, B., Luizao, F., Miller, S., Markewitz, D., Nobre, 
A. D., Nobre, C. A., Filho, N. P., da Rocha, H., Dias, P. S., von Randow, C., and Vourlitis, G. L.: Ecological research in the largescale biosphere-atmosphere experiment in Amazonia: Early results, Ecol. Appl., 14, 3-16, 2004.

Kistler, R., Kalnay, E., Collins, W., Saha, S., White, G., Woollen, J., Chelliah, M., Ebisuzaki, W., Kanamitsu, M., Kousky, V., van den Dool, H., Jenne, R., and Fiorino, M.: The NCEP-NCAR 50-year reanalysis: Monthly means CD-ROM and documentation, Bull. Am. Meteorol. Soc., 82, 247-267, 2001.

Kleidon, A. and Heimann, M.: Assessing the role of deep rooted vegetation in the climate system with model simulations: mechanism, comparison to observations and implications for Amazonian deforestation, Clim. Dynam., 16, 183-199, 2000.

Koster, R., Dirmeyer, P., Guo, Z., Bonan, G., Chan, E., Cox, P., Gordon, C., Kanae, S., Kowalczyk, E., Lawrence, D., Liu, P., Lu, C., Malyshev, S., McAvaney, B., Mitchell, K., Mocko, D., Oki, T., Oleson, K., Pitman, A., Sud, Y., Taylor, C., Verseghy, D., Vasic, R., Xue, Y., Yamada, T., and Team, G.: Regions of strong coupling between soil moisture and precipitation, Science, 305, 1138-1140, 2004a.

Koster, R. D., Suarez, M. J., Liu, P., Jambor, U., Berg, A., Kistler, M., Reichle, R., Rodell, M., and Famiglietti, J.: Realistic initialization of land surface states: Impacts on subseasonal forecast skill, J. Hydrometeorol., 5, 1049-1063, 2004b.

Krinner, G., Viovy, N., de Noblet-Ducoudre, N., Ogee, J., Polcher, J., Friedlingstein, P., Ciais, P., Sitch, S., and Prentice, I.: A dynamic global vegetation model for studies of the coupled atmosphere-biosphere system, Global Biogeochem. Cy., 19, 133, 2005.

Lewis, S., Brando, P., Phillips, O., van der Heijden, G., and Nepstad, D.: The 2010 Amazon Drought, Science, 331, 554-554, 2011.

Li, W., Fu, R., and Dickinson, R.: Rainfall and its seasonality over the Amazon in the 21st century as assessed by the coupled models for the IPCC AR4, J. Geophys. Res.-Atmos., 111, D02111, doi:10.1029/2005JD006355, 2006.

Li, W., Fu, R., Juárez, R., and Fernandes, K.: Observed change of the standardized precipitation index, its potential cause and implications to future climate change in the Amazon region, Philos. T. R. Soc. B, 363, 1767-1772, 2008.

Liang, X., Xie, Z., and Huang, M.: A new parameterization for surface and groundwater interactions and its impact on water budgets with the variable infiltration capacity (VIC) land surface model, J. Geophys. Res.-Atmos., 108, 8613-8629, doi:10.1029/2002JD003090, 2003.

Mahfouf, J.-F., Ciret, C., Ducharne, A., Irannejad, P., Noilhan, J., Shao, Y., Thornton, P., Xue, Y., and Yang, Z.-L.: Analysis of transpiration results from the RICE and PILPS workshop, Global Planet. Change, 13, 73-88, 1996.

Manabe, S.: Climate and ocean circulation .I. Atmospheric circulation and hydrology of earths surface, Mon. Weather Rev., 97, 739-774, 1969.

Manning, R.: On the flow of water in open channels and pipes, Trans. Inst. Civil Engrs (Dublin, Ireland), 20, 179-207, 1895.

Marengo, J.: On the hydrological cycle of the Amazon Basin: A historical review and current state-of-the-art, Rev. Bras. Meterol., 21, 1-19, 2006.

McMurtrie, R., Rook, D., and Kelliher, F.: Modelling the yield of Pinus radiata on a site limited by water and nitrogen, Forest Ecol. Manag., 30, 381-413, 1990.
McNab, A. L.: Climate and drought, Trans. Am. Geophys. Union, 70, 873-883, 1989.

Meir, P. and Ian Woodward, F.: Amazonian rain forests and drought: response and vulnerability, New Phytol., 187, 553-557, 2010.

Miguez-Macho, G. and Fan, Y.: The role of groundwater in the Amazon water cycle: 1. Influence on seasonal streamflow, flooding and wetlands, J. Geophys. Res.-Atmos., 117, D15113, doi:10.1029/2012JD017539, 2012.

Miller, J., Russell, G., and Caliri, G.: Continental-scale river flow in climate models, J. Climate, 7, 914-928, 1994.

Miralles, D. G., Holmes, T. R. H., De Jeu, R. A. M., Gash, J. H., Meesters, A. G. C. A., and Dolman, A. J.: Global land-surface evaporation estimated from satellite-based observations, Hydrol. Earth Syst. Sci., 15, 453-469, doi:10.5194/hess-15-453-2011, 2011.

Molinier, M. and Guyot, J.: Les régimes hydrologiques de l'Amazone et de ses affluents, IAHS-AISH P., 238, 209-222, 1996.

Mortatti, J., Moraes, J., Victoria, R., and Martinelli, L.: Hydrograph separation of the Amazon river: a methodological study, Aquat. Geochem., 3, 117-128, 1997.

Mualem, Y.: A new model for predicting the hydraulic conductivity of unsaturated porous media, Water Resour. Res., 12, 513-522, doi:10.1029/WR012i003p00513, 1976.

Mueller, B. and Seneviratne, S.: Systematic land climate and evapotranspiration biases in CMIP5 simulations, Geophys. Res. Lett., 41, 128-134, doi:10.1002/2013GL058055, 2014.

Mueller, B., Seneviratne, S., Jimenez, C., Corti, T., Hirschi, M., Balsamo, G., Ciais, P., Dirmeyer, P., Fisher, J., Guo, Z Jung, M., Maignan, F., McCabe, M. F., Reichle, R., Reichstein, M., Rodell, M., Sheffield, J., Teuling, A. J., Wang, K., Wood, E. F., and Zhang, Y.: Evaluation of global observations-based evapotranspiration datasets and IPCC AR4 simulations, Geophys. Res. Lett., 38, L06402, doi:10.1029/2010GL046230, 2011.

Nepstad, D. C., de Carvalho, C. R., Davidson, E. A., Jipp, P. H., Lefebvre, P. A., Negreiros, G. H., da Silva, E. D., Stone, T. A., Trumbore, S. E., and Vieira, S.: The role of deep roots in the hydrological and carbon cycles of Amazonian forests and pastures, Nature, 372, 666-669, 1994.

New, M., Hulme, M., and Jones, P.: Representing twentieth-century space-time climate variability. Part II: Development of 1901-96 monthly grids of terrestrial surface climate, J. Climate, 13, 2217 2238, 2000.

Ngo-Duc, T., Laval, K., Ramillien, G., Polcher, J., and Cazenave, A.: Validation of the land water storage simulated by Organising Carbon and Hydrology in Dynamic Ecosystems (ORCHIDEE) with Gravity Recovery and Climate Experiment (GRACE) data, Water Resour. Res., 43, W04427, doi:10.1029/2006WR004941, 2007.

Niu, G.-Y., Yang, Z.-L., Dickinson, R., Gulden, L., and Su, H.: Development of a simple groundwater model for use in climate models and evaluation with Gravity Recovery and Climate Experiment data, J. Geophys. Res.-Atmos., 112, D07103, doi:10.1029/2006JD007522, 2007.

Olson, J., Watts, J., and Allison, L.: Carbon in live vegetation of major world ecosystems, Tech. rep., Oak Ridge National Laboratory, Oak Ridge, Tennessee, USA, 1983. 
Paiva, R., Collischonn, W., and Tucci, C.: Large scale hydrologic and hydrodynamic modeling using limited data and a GIS based approach, J. Hydrol., 406, 170-181, 2011.

Paiva, R. C. D., Collischonn, W., Bonnet, M. P., and de Gonçalves, L. G. G.: On the sources of hydrological prediction uncertainty in the Amazon, Hydrol. Earth Syst. Sci., 16, 3127-3137, doi:10.5194/hess-16-3127-2012, 2012.

Paiva, R. C. D. d., Buarque, D. C., Collischonn, W., Bonnet, M.-P., Frappart, F., Calmant, S., and Bulhões Mendes, C. A.: Large-scale hydrologic and hydrodynamic modeling of the Amazon River basin, Water Resour. Res., 49, 1226-1243, doi:10.1002/wrcr.20067, 2013.

Pan, M., Sahoo, A. K., Troy, T. J., Vinukollu, R. K., Sheffield, J., and Wood, E. F.: Multisource estimation of long-term terrestrial water budget for major global river basins, J. Climate, 25, 31913206, 2012.

Pitman, A.: The evolution of, and revolution in, land surface schemes designed for climate models, Int. J. Climatol., 23, 479510, 2003.

Pokhrel, Y. N., Fan, Y., Miguez-Macho, G., Yeh, P. J.-F., and Han, S.-C.: The role of groundwater in the Amazon water cycle: 3. Influence on terrestrial water storage computations and comparison with GRACE, J. Geophys. Res.-Atmos., 118, 3233-3244, doi:10.1002/jgrd.50335, 2013.

Polcher, J.: Les processus de surface à l'échelle globale et leurs interactions avec l'atmosphère, Habilitation à diriger des recherches, Université Paris VI, 2003.

Reichle, R. H. and Koster, R. D.: Global assimilation of satellite surface soil moisture retrievals into the NASA Catchment land surface model, Geophys. Res. Lett., 32, L02404, doi:10.1029/2004GL021700, 2005.

Richards, L. A.: Capillary conduction of liquids through porous mediums, Physics, 1, 318-333, 1931.

Schneider, U., Becker, A., Finger, P., Meyer-Christoffer, A., Ziese, M., and Rudolf, B.: GPCC's new land surface precipitation climatology based on quality-controlled in situ data and its role in quantifying the global water cycle, Theor. Appl. Climatol., 115, $15-40,2014$.

Sheffield, J., Goteti, G., and Wood, E.: Development of a 50-year high-resolution global dataset of meteorological forcings for land surface modeling, J. Climate, 19, 3088-3111, 2006.

Shuttleworth, W.: Evaporation from Amazonian rainforest, Proc. R. Soc. London, Ser. B, 233, 321-346, 1988.

Swenson, S. and Wahr, J.: Methods for inferring regional surfacemass anomalies from Gravity Recovery and Climate Experiment (GRACE) measurements of time-variable gravity, J. Geophys. Res.-Sol Ea., 107, 2193, doi:10.1029/2001JB000576, 2002.

Swenson, S. and Wahr, J.: Post-processing removal of correlated errors in GRACE data, Geophys. Res. Lett., 33, L08402, doi:10.1029/2005GL025285, 2006.

Swenson, S., Wahr, J., and Milly, P.: Estimated accuracies of regional water storage variations inferred from the Gravity Recovery and Climate Experiment (GRACE), Water Resour. Res., 39, 1223, doi:10.1029/2002WR001808, 2003.

Syed, T., Famiglietti, J., Chen, J., Rodell, M., Seneviratne, S., Viterbo, P., and Wilson, C.: Total basin discharge for the Amazon and Mississippi River basins from GRACE and a landatmosphere water balance, Geophys. Res. Lett., 32, L24404, doi:10.1029/2005GL024851, 2005.
Syed, T. H., Famiglietti, J. S., Rodell, M., Chen, J., and Wilson, C. R.: Analysis of terrestrial water storage changes from GRACE and GLDAS, Water Resour. Res., 44, W02433, doi:10.1029/2006WR005779, 2008.

Thompson, S. L. and Pollard, D.: A global climate model (GENESIS) with a land-surface transfer scheme (LSX). Part I: Present climate simulation, J. Climate, 8, 732-761, 1995.

Trigg, M., Wilson, M., Bates, P., Horritt, M., Alsdorf, D., Forsberg, B., and Vega, M.: Amazon flood wave hydraulics, J. Hydrol., 374, 92-105, 2009.

Van Genuchten, M. T.: A closed-form equation for predicting the hydraulic conductivity of unsaturated soils, Soil Sci. Soc. Am. J., 44, 892-898, 1980.

Verbeeck, H., Peylin, P., Bacour, C., Bonal, D., Steppe, K., and Ciais, P.: Seasonal patterns of $\mathrm{CO}_{2}$ fluxes in Amazon forests: Fusion of eddy covariance data and the ORCHIDEE model, J. Geophys. Res.-Biogeo., 116, G02018, doi:10.1029/2010JG001544, 2011.

Vergnes, J.-P. and Decharme, B.: A simple groundwater scheme in the TRIP river routing model: global off-line evaluation against GRACE terrestrial water storage estimates and observed river discharges, Hydrol. Earth Syst. Sci., 16, 3889-3908, doi:10.5194/hess-16-3889-2012, 2012.

Viovy, N.: Interannuality and $\mathrm{CO}_{2}$ sensitivity of the SECHIBABGC coupled SVAT-BGC model, Phys. Chem. Earth, 21, 489497, 1996.

Viterbo, P. and Beljaars, A. C.: An improved land surface parameterization scheme in the ECMWF model and its validation, $\mathrm{J}$. Climate, 8, 2716-2748, 1995.

Vörösmarty, C., Fekete, B., Meybeck, M., and Lammers, R.: Global system of rivers: Its role in organizing continental land mass and defining land-to-ocean linkages, Global Biogeochem. Cy., 14, 599-621, 2000.

Wahr, J., Swenson, S., Zlotnicki, V., and Velicogna, I.: Timevariable gravity from GRACE: First results, Geophys. Res. Lett., 31, L11501, doi:10.1029/2004GL019779, 2004.

Xavier, L., Becker, M., Cazenave, A., Longuevergne, L., Llovel, W., and Filho, O. R.: Interannual variability in water storage over 2003-2008 in the Amazon Basin from GRACE space gravimetry, in situ river level and precipitation data, Remote Sens. Environ., 114, 1629-1637, 2010.

Yamazaki, D., Lee, H., Alsdorf, D., Dutra, E., Kim, H., Kanae, S., and Oki, T.: Analysis of the water level dynamics simulated by a global river model: A case study in the Amazon River, Water Resour. Res., 48, W09508, doi:10.1029/2012WR011869, 2012.

Yeh, P. J.-F., Swenson, S., Famiglietti, J., and Rodell, M.: Remote sensing of groundwater storage changes in Illinois using the Gravity Recovery and Climate Experiment (GRACE), Water Resour. Res., 42, W12203, doi:10.1029/2006WR005374, 2006.

Zeng, Z., Wang, T., Zhou, F., Ciais, P., Mao, J., Shi, X., and Piao, S.: A worldwide analysis of spatiotemporal changes in water balance based evapotranspiration from 1982 to 2009, J. Geophys Res.-Atmos., 119, 1186-1202, doi:10.1002/2013JD020941, 2014.

Zhang, K., Kimball, J., Nemani, R., and Running, S.: A continuous satellite-derived global record of land surface evapotranspiration from 1983 to 2006, Water Resour. Res., 46, W09522, doi:10.1029/2009WR008800, 2010. 
Zhu, Z., Bi, J., Pan, Y., Ganguly, S., Anav, A., Xu, L., Samanta, A., Piao, S., Nemani, R. R., and Myneni, R. B.: Global data sets of vegetation leaf area index (LAI) $3 \mathrm{~g}$ and Fraction of Photosynthetically Active Radiation (FPAR) 3g derived from Global Inventory Modeling and Mapping Studies (GIMMS) Normalized Difference Vegetation Index (NDVI3g) for the period 1981 to 2011, Remote Sens., 5, 927-948, 2013.
Zobler, L.: A world soil file for global climate modeling, Tech. Rep. 87802, NASA, 1986. 